\title{
Toxic Legacy
}

\section{The Environmental Impact of the Manufactured Gas Industry in the United States}

\author{
JOEL A. TARR
}

\section{Introduction}

Historically, the development and production of energy from fossil fuels have had large impacts on the environment and on human health. Concern today over coal-mining methods, coal-combustion wastes, natural gas exploitation, oil spills, and emissions from both fuel consumption and treatment processes highlight society's dilemma about ensuring energy supplies without damaging the environment or further altering the earth's climate balance. While historians have paid some attention to the environmental effects of fossil fuel-processing techniques involving coal and petroleum, little has been written about the environmental history of another massive user of fossil fuels: the manufactured gas or town gas industry in the United States. ${ }^{1}$

Joel A. Tarr is the Richard S. Caliguiri University Professor of History and Policy at Carnegie Mellon University. His main research interests are in the history of the urban environment and urban infrastructure systems. He is the author of The Search for the Ultimate Sink: Urban Pollution in Historical Perspective (1996), The Horse in the City: Living Machines in the 19th Century (with coauthor Clay McShane, 2007), the editor of Devastation and Renewal: An Environmental History of Pittsburgh and Its Region (2004), and The Rise of the Networked City in Europe and America (coedited with Gabriel Dupuy, 1988). His articles and papers have appeared in numerous journals and edited volumes. In 2008, SHOT awarded him its Leonardo da Vinci Medal for outstanding contributions to the field. He would like to thank Christopher Castaneda, Hugh Gorman, Pat Malone, Anthony Penna, Joe Pratt, Christine Rosen, and Leslie Tomory for their help during the long period of this article's gestation, and also several $T \& C$ reviewers for their helpful comments. A considerable amount of the material used in this article was gathered while he served as a consultant to law firms involved in litigation involving the industry.

(C)2014 by the Society for the History of Technology. All rights reserved. 0040-165X/14/5501-0004/107-47

1. The most important study for information regarding the history of manufactured gas plants sites is Allen W. Hatheway, Remediation of Former Gas Plants and Other Coal- 
This article will explore the history of the effects of manufactured gas on air, water, and land environments from the time of its introduction through its disappearance as an urban energy source. It will examine the gradual attempts by the courts and state and local legislatures to reduce the negative effects of gas-industry pollution, and the manner in which the

JANUARY

2014

VOL. 55 industry itself dealt with these issues. Natural gas began replacing manufactured gas in the early twentieth century, a trend that accelerated in the 1930s with improvements in pipeline technology. After World War II the substitution increased, with the last municipal manufactured gas facility closing in the 1970s (fig. 1). The industry's disappearance, however, did not end its environmental impacts, but rather left the nation with a major legacy of badly contaminated sites.

The article will consider this legacy and the industry's lack of attention to site pollution as it transitioned to natural gas. A major issue involves the role of gas engineers and plant managers in the creation of these polluted sites. Were gas engineers aware of the air, water, and land damages that the manufactured gas technology and their waste-disposal methods could produce? Did they possess what would today be identified as "environmental values," or were production and profit their major goals regardless of the impacts? Where does the responsibility lie for creation of this pollution legacy? Hopefully, this review of the history of the manufactured gas industry in regard to its waste-disposal practices will help clarify these questions.

Manufactured gas is an energy source that provided cities in the United States and throughout the world with light and power during much of the period from approximately 1850 to 1950 . It differs from natural gas in composition: natural gas consists primarily of methane with a Btu rating of approximately 1,000 per standard cubic foot (SCF), while manufactured gas is a mixture of hydrogen, carbon monoxide, methane, and hydrocarbons, with small amounts of carbon dioxide, hydrogen sulfide, and nitrogen. It has a Btu rating of 550-600 SCF. The types of gas produced over time were primarily coal gas, blue gas, carbureted water gas, and oil gas. In addition, many factories made a low-Btu gas called "producer gas" for their own use. ${ }^{2}$

Tar Sites. Hatheway, a geological engineer, had already put large sections of his work on the internet, but his encyclopedic and profusely illustrated book goes considerably further. It contains extensive discussions of the technology of gas manufacturing and its changes over time, and provides detailed information regarding the mechanisms and sources for understanding site contamination. Although not a historian, Hatheway's book contains an extensive record of the literature of manufactured gas, its regulation, its waste-disposal practices, and the process of site remediation. None of the company histories of U.S. gas and electric firms treats environmental effects. On the manufactured gas and natural gas industries, see Christopher Castaneda, Invisible Fuel; Leslie Tomory, Progressive Enlightenment, "The Environmental History of the Early British Gas Industry, 1812-1830," and "Building the First Gas Network 1812-1920; and Peter Thorsheim, Inventing Pollution.

2. F. W. Steere, "Producer Gas Technology"; Hatheway, Remediation of Former Gas Plants and Other Coal-Tar Sites, 174-202. 


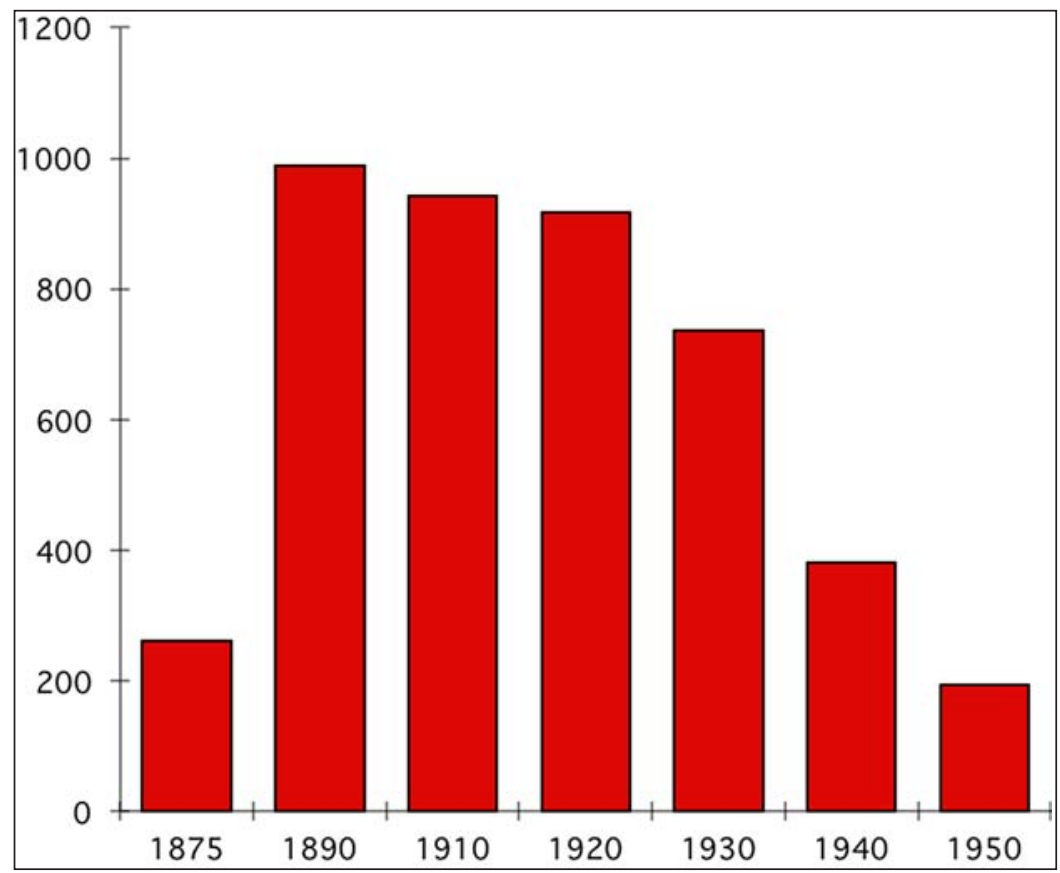

FIG. 1 U.S. manufactured gas plants, 1875-1950. (Sources: Fredik E. Saward, American Gas Making [New York, 1878]; and Robert Eng, Survey of Town Gas and By-Product Production and Locations in the U.S. (1880-1950) [McLean, VA, 1985].)

\section{A Brief History of the Industry}

The origins of gas lighting rested on research into the effects of the destructive distillation of wood and coal and developments in pneumatic chemistry in the late eighteenth and early nineteenth centuries. By 1800, a number of engineers and entrepreneurs in Great Britain and Europe were exploring the development and use of gas for lighting. In 1807, the London and Westminster Gas Light and Coke Company began providing streetlights in the city, and by 1820 , it had 120 miles of mains and over 30,000 customers. $^{3}$

Emulation in the United States rapidly followed. In 1816, the Baltimore municipal government granted the Gas Light Company of that city a franchise to lay pipe for gas distribution; other cities followed its lead, using a variety of feedstocks, such as rosin, wood, and distillate of turpentine, as well as cannel coal, to generate gas. By the middle of the century, canals and railroads provided transport of bituminous coal ("gas coal") from

3. This paragraph and the following one are based on Tomory, Progressive Enlightenment. 
JANUARY

2014

VOL. 55

trans-Appalachian coalfields to furnish fuel to gas plants in eastern urban markets (see fig. 1). The superiority of this fuel for gas-making and its low cost compared to other fuels greatly enlarged the gas-lighting market. ${ }^{4}$

The U.S. Census reported the operation of thirty municipal manufactured or town gas plants in 1850, but easier access to bituminous coal stimulated a rapid rise in their number: 390 (1869), 742 (1890), and 1,296 (1909). More than half of the firms, with over 50 percent of the labor and capital, were located in cities in the four states of New York, Massachusetts, Pennsylvania, and Ohio. Estimates of the total number of gas plants in the nation, both centralized and isolated-such as producer-gas units-undoubtedly reached into the many thousands. ${ }^{5}$

The coal gas-manufacturing process involves destructively distilling the mineral in a retort to drive out the volatiles and produce gas. A typical nineteenth-century "bench" consisted of six or more retorts, and a producer-gas furnace that used coal for heating the retorts; coke produced from the coal and tar condensed from the gas were also used as retort fuels. From the retort, the gases were drawn off into a hydraulic main where some of the vapors became "wastes" consisting of tars and contaminated liquids. The gas was run into a condenser from the hydraulic main, where it was cooled and other impurities removed. Often, the gas was funneled into an exhauster that further cooled it. Additional impurities were washed from the gas by running it through beds of moist lime, iron oxides, or wood chips. The final step in the production process was to store the gas in a gasometer or storage tank before distribution via street mains to customers ${ }^{6}$ (fig. 2).

Over time, inventors and engineers made a number of significant improvements and refinements in the manufacturing process, including the development of water gas, carbureted water gas (water gas sprayed with liquid hydrocarbons and thermally cracked), more efficient purification processes and separators, and larger and more secure gasometers. ${ }^{7}$ Thaddeus S. C. Lowe's 1873 invention of water gas or blue gas was a major factor in stimulating the industry's expansion. This method worked by passing high-pressure steam over hot coal or coke, thereby forming a gas of carbon monoxide and pure hydrogen. The gas was then cooled and scrubbed and passed through water vapor, leaving pure hydrogen gas or water gas. Water or blue gas had a lower illuminating value than did coal gas, but in 1875, Lowe found that if he sprayed blue gas with liquid hydro-

4. Joel A. Tarr, "Transforming an Energy System," 19-21.

5. Ibid., 21-22; Hatheway, Remediation of Former Gas Plants and Other Coal-Tar Sites, 4-11.

6. See "History of Manufactured Gas," available at http://en.wikipedia.org/wiki/ History_of_manufactured_gas; and Tomory, Progressive Enlightenment, 67-120.

7. Gas oil was relatively inexpensive at this time because the oil industry had only limited markets; fuel demands for the internal combustion engine changed this in the twentieth century. 
TARR | Toxic Legacy

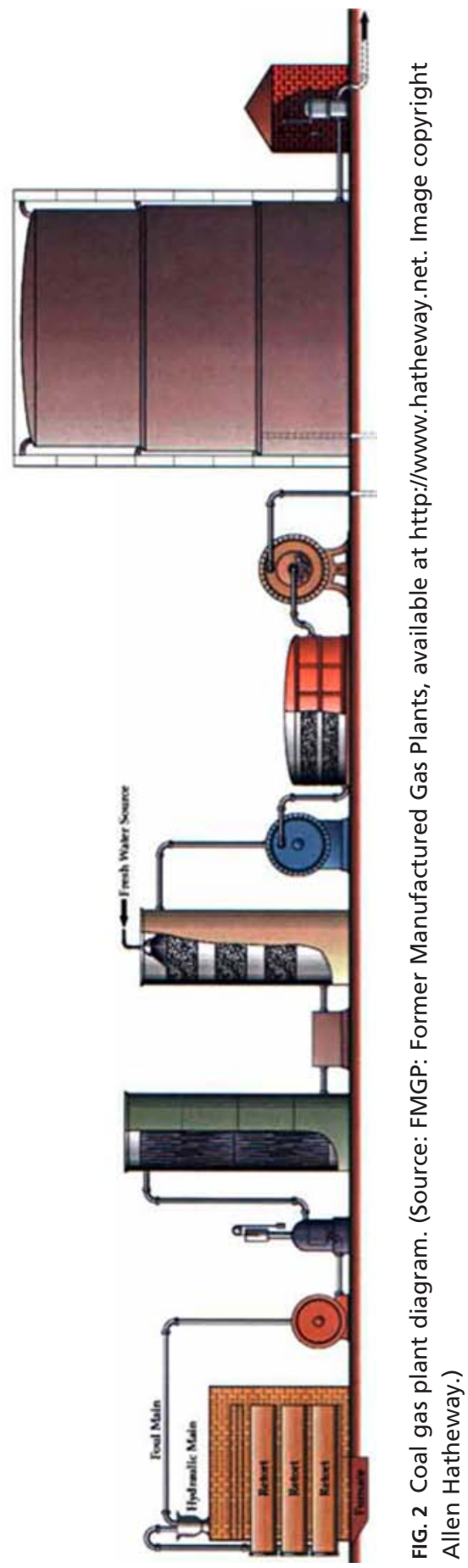


JANUARY

2014

VOL. 55

carbons, he produced a gas he called "carbureted water gas" with a Btu (SCF) range between 500 and $600 .^{8}$

A further boost to the industry occurred in 1885, when German chemist Carl Auer von Welsbach patented a gas mantle made of cotton fabric impregnated with rare earth that produced a steady white light of between 30-50 candlepower. This increased the illumination that could be obtained from a given quantity of gas by about a factor of six. The mantle provided an inexpensive and superior incandescent lamp for the illumination market to meet the competition of the electric light. ${ }^{9}$

Initially, by-products from gas manufacturing like tar, benzene, and ammonia had little use and manufactured gas plants (MGPs) often discarded or "wasted" them, although coke and tar were occasionally used as fuels. By the end of the century, however, by-products like coal tars had become important chemical feedstocks for the dye and chemical industries. ${ }^{10}$ The essential nature of the manufacturing process for the production of manufactured gas, however, remained the same in spite of scale changes by using heat to destructively distill coal or other organic fuel to drive out the volatiles and produce gas (fig. 3 ).

Urban gas utilities generated fuel for their customers from a central plant (or several plants in the case of large utilities) and distributed it through a piped system. MGPs became part of a growing centralized infrastructure network that by the late nineteenth century provided cities with water, sanitary services, telegraph and telephone facilities, and gas and electricity. ${ }^{11}$ While some municipally owned plants existed, the largest of which was the Philadelphia Gas Works, most were private. Municipalities regarded MGPs as public utilities and required that they acquire franchises to use the city streets for their distribution lines. They also regulated price and set luminosity ("candlepower") requirements.

In 1885, Massachusetts created a State Gas Commission, thereby initiating state regulation of the manufactured gas industry, and by 1906, twenty-nine states had regulatory commissions with various powers. These commissions were primarily concerned with issues relating to the quality of the gas, price, and service; they resembled numerous other state regulatory commissions created during the late nineteenth and early decades of

8. Utilities were initially slow to adopt the water gas process because of concerns over its health effects, and for several years, Massachusetts and New Jersey outlawed the distribution of illuminating gas containing 10 percent or more of carbon monoxide. W. T. Sedgwick and F. Schneider Jr.'s "On the Relation of Illuminating Gas to Public Health" shows statistically how deaths from carbon-monoxide poisoning from illuminating gas had increased rapidly with the introduction of water gas.

9. For more on the Welsbach gas mantle and the regulatory changes, see Tarr, "Transforming an Energy System," 22-25.

10. Charles E. Munroe, "By-Products in Gas Manufacture."

11. Tomory, Progressive Enlightenment, 243-44; Joel A. Tarr, "The City and Technology," 97-112. 


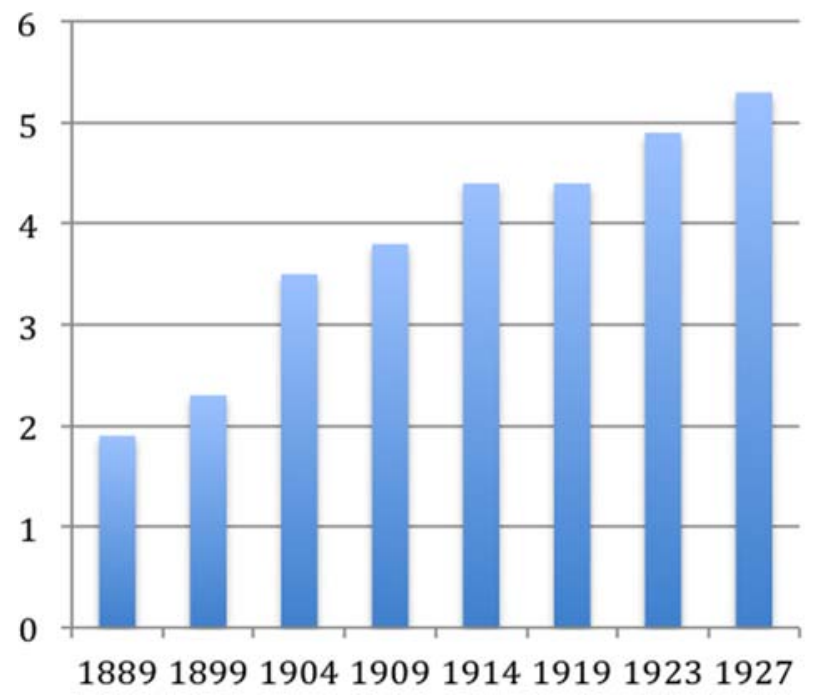

FIG. 3 Percentage of coal use by the manufactured gas industry of total bituminous coal use (1889-1927). (Source: U.S. Bureau of Mines, Mineral Resources [Washington, DC, 1927], pt. 2:423.)

the twentieth century during the Progressive Era. ${ }^{12}$ Battles between utility firms and municipal and state authorities over issues like price, luminosity, energy ratings, and technology, as well as the price and duration of franchises, were a frequent occurrence.

After its discovery, carbureted water gas rapidly supplanted coal gas as the principal industry product. ${ }^{13}$ In 1890 , the census reported that 46.7 percent of the 742 municipal gas firms produced coal gas, 38 percent made water gas, and the remainder mixed coal and water gas. In 1914, however, the industry produced 44.2 percent water gas, 36.4 percent mixtures of coal and water gas, and 5.2 percent coal gas. Between 1914 and 1929, the total amount of distributed manufactured gas of all kinds more than doubled, from approximately 204 billion cubic feet to over 450 billion, as both domestic and industrial use increased ${ }^{14}$ (see fig. 3 ). In addition, during the 1920 s, the coke industry became a significant supplier of manufactured gas,

12. A full list of state regulatory agencies with their founding dates is in Hatheway, Remediation of Former Gas Plants and Other Coal-Tar Sites, 759-65. For state regulatory commissions in general, see Werner Troesken, "Regime Change and Corruption."

13. Derek Matthews argues that MGPs in the United States opted heavily for water gas production, while British firms chose stoking machinery improvements and European firms favored gravity stoking because of the relative cost of raw materials. Oil to enrich water gas was far cheaper in the United States than in either Great Britain or Europe. See Matthews, "The Technical Transformation of the Late-Nineteenth-Century Gas Industry," 967-80.

14. Tarr, "Transforming an Energy System," 23-24. 


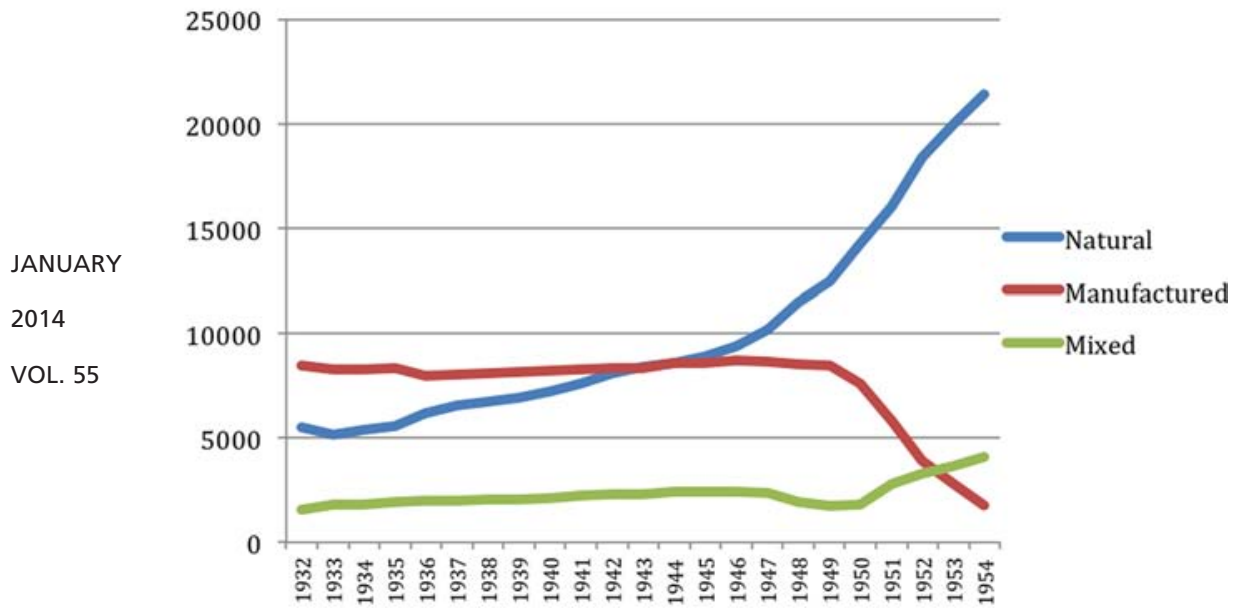

FIG. 4 Gas customers $(1,000)$ of utilities by type (1932-54). (Source: Compiled from U.S. Bureau of Mines, Mineral Resources [Washington, DC, 1932-54].)

as it shifted from beehive to by-product ovens to produce coke for the iron and steel industry and to capture the valuable by-products. The by-product firms produced a gas surplus that was marketed, and by 1930, 25 percent of the manufactured gas distributed by utilities to U.S. domestic, commercial, and industrial customers came from by-product ovens ${ }^{15}$ (fig. 4).

Over the course of its history, significant changes occurred on the demand side for manufactured gas. Gas was primarily used for lighting, first in streets and factories and then in residences throughout most of the nineteenth century. ${ }^{16}$ By the end of the century, however, gas utilities were exploiting the market for cooking and heating, as well as for industrial and other uses, such as the gas engine, as they competed with the growing electrical-supply industry for the lighting market. By the 1920s and '30s, the consumption of manufactured gas for lighting diminished sharply, but its domestic use in gas stoves and house heaters, as well as for industrial and commercial uses, compensated for the market loss. ${ }^{17}$ While pipeline improvements enabled natural gas to substitute for manufactured gas in some western cities close to gas fields during the 1920s and '30s, the most dramatic decline for manufactured gas occurred in the post-World War II period (fig. 5).

15. A. C. Fieldner, "Recent Developments in By-Products from Bituminous Coal," 3.

16. Wolfgang Schivelbusch, Disenchanted Night, 1-50.

17. Jacob Martin Gould, Output and Productivity in the Electric and Gas Utilities, 84-90. Gas for industrial and commercial uses was sold at a lower price than that for domestic use. 


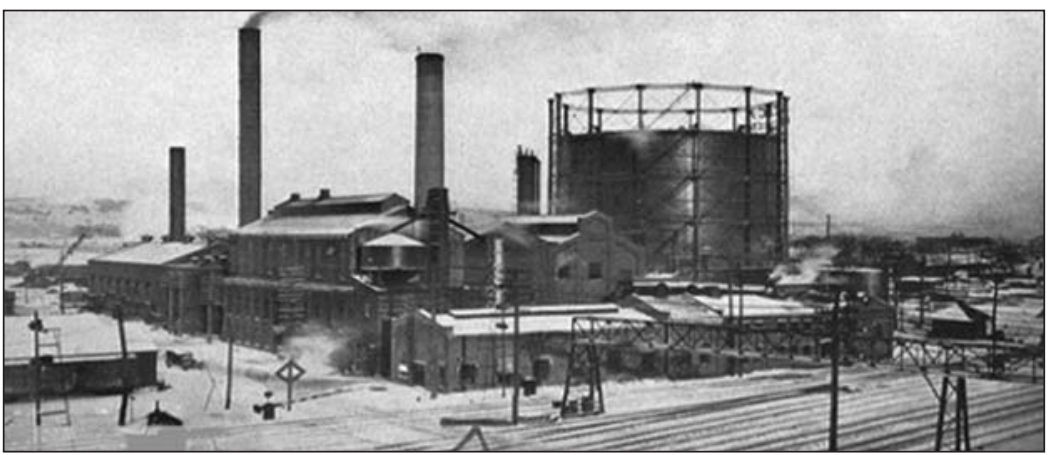

FIG. 5 A conventional manufactured gas plant, ca.1920. Washington Street Station (steam plant and gas-generating plant), Utica Gas and Electric Company, Utica, New York (1923). (Source: Utica Gas and Electric Company, The Upper Mohawk Valley: Land of Industry [Utica, NY: UGEC, 1923], 111.)

\section{Environmental Effects of the Manufactured Gas Industry}

Various governments, courts, and affected parties early identified the manufactured gas industry as a significant polluter of water, air, and land. The pollution was derived from normal plant operations, accidents, technological failures, faulty means of storage, and the deliberate "wasting" of by-products. ${ }^{18}$ These wastes included tars, ammonia, overflow liquors from settling tanks, drips (liquids from condensed gas), leaks from wooden and masonry tanks sunk in the ground, spills that contaminated soil and groundwater with oils and tar, and tars mixed with other wastes for landfills. Pollution occurred both on- and off-site. Tars and oils frequently saturated plant grounds and penetrated deeply into the soil. While a few articles about on-site pollution appeared in the industry literature and firms made some attempts to reduce spills, they largely did not investigate nor identify the extent of site pollution until years after the industry had ceased to operate. ${ }^{19}$ Off-site air, land, and water pollution, however, was documented much more extensively in the public record.

18. Munroe, "By-Products in Gas Manufacture," 13-14. Another negative impact was gas leakage from MGP distribution pipes, which contaminated soil and was frequently blamed for the destruction of trees in urban areas; see Carl G. Deuber, "Effects on Trees of an Illuminating Gas in the Soil."

19. See, for instance, Arthur T. Safford, "Wastes from Lowell Gas Light Company's Yards," 169-98. Several sources commented that the sites of small plants often tended to be especially badly contaminated with tars and oil. See report, Engineering Department, Massachusetts State Board of Health, to X. H. Goodnough, Chief Engineer, State Board of Health, "Pollution of Malden River," 30 March 1908, "Reports of Water Supply and Sewerage," vol. 2, July to September 1908, 135, in Archives of the Massachusetts Board of Health, Boston (hereafter A-MSBH); and Safford, "Wastes from Lowell Gas Light Company's Yards." 
For instance, MGPs were often cited as sources of noxious fumes. Residents living near the manufactured gas plants frequently complained about the "gas nuisance" - the various odors emanating from gas-making, including the rotten-egg smell of hydrogen sulfide, ammonia odors, and nauseating stenches from the lime used in the gas purifier. ${ }^{20}$ In response to

JANUARY

2014

VOL. 55 citizens' complaints, courts and boards of health in cities plagued by the obnoxious odors attempted to reduce them through threats of fines and injunctions. Christine Rosen has noted that while courts during the 184064 period were prone to tolerate pollution from new industries like iron and textile mills, the pollution emitted by gas manufacturers "generated such awful smells, smokes, and water pollution" that the courts often put MGPs on their list of creators of prima facie nuisances. ${ }^{21}$

Problems with pollution from the gas nuisance persisted into the twentieth century. Three examples reflect these problems, as well as the difficulty, in eliminating them without the courts and regulatory agencies being ready to take vigorous action. The $1869 \mathrm{New}$ Jersey case of Cleveland et al. vs. Citizens Gas Light Company demonstrates the actions of a court willing to take a strong stand on this issue.

In 1869 , the residents of four homes in a residential section of Newark sued to prevent construction of an MGP near their homes on the grounds that it would "greatly injure their value, and render them unfit for residences; that gas works always and necessarily send forth noisome and unpleasant vapors and smoke." The judge commented that it was well-known that MGPs produced odor nuisances, especially those stemming from the use of the lime process of purification. He held that while the court would not issue an injunction to prevent the plant's construction, it would forbid it from using the lime process or "from manufacturing gas in any way that will produce any annoyance to persons dwelling in the houses of the complainants, by any smoke, gases, other effluvia or odors, that may issue from the works." 22

Action against the gas nuisance, however, was not always so successful. In the 1860s, New York City's newly established Metropolitan Board of Health became the first U.S. governmental entity whereby municipal health officials tried to use their regulatory powers to curb industrial pollutionin this case, the gas nuisance created by the city's MGPs. Several years of controversy ensued, involving hearings, investigations by leading chemists,

20. The case of Commonwealth vs. The Worcester Gas Light Company (1855) includes arguments about the health effects of MGP odors, including expert testimony by Yale professor of chemistry Benjamin Silliman Jr. that the odors from gas were not injurious to health; see Edward W. Lincoln, Trial. For a legal case in which the plaintiff successfully sued a gas company on the basis of noxious odors, see Bohan vs. Port Jervis Gas Light Company, 122 N.Y. 18, 24 N. E. 246, 9 L. R. A. 711 (1890).

21. Christine Meisner Rosen, “'Knowing' Industrial Pollution," 585.

22. Cleveland et al. vs. Citizens Gas Light Company, 20 N.J. Eq. 201 (5 C. E. Green) (1869); Ottawa Gas Light Company vs. Thompson, 39 Illinois, 596 (1864). 
and the courts. While the board's action produced some temporary relief, nuisances resumed in the early 1870s. The courts now took the position that it was unreasonable to hold an offending company liable for causing a nuisance that it lacked the capacity to fully abate, especially since it was difficult to distinguish gas fumes from other industrial stenches. Although New York City's Board of Health was at this time the only municipal government agency willing to attempt to control stenches from gas plants and other industrial sources, it lacked the power to eliminate them. ${ }^{23}$

The persistence of the gas nuisance in the face of efforts to control it is also reflected in the situation of the New England Gas and Coke Company. Soon after the plant opened in 1898, fumes from its operations enveloped the nearby town of Chelsea. The town's mayor protested to the Massachusetts State Board of Health, and the board's investigation showed that the odors were coming from settling basins for plant wastes, as well as from gas-purifying tanks that used lime and iron oxide to remove sulfur impurities. ${ }^{24}$ While further investigation showed that the company had partially reduced the odors by changing its purification technology, complaints continued over the following years. In the early 1930s, unlike its past actions, the Massachusetts Department of Health (formerly the Board of Health) refused to move against the company, arguing that it, as well as other industries, was attempting to mitigate the problem. ${ }^{25}$ As justification for its refusal to take strong action, the department cited a 1925 Massachusetts Supreme Court decision that "disagreeable odors [were] one of the annoyances and inconveniences which every one in such a [industrial] neighborhood must endure." 26

These cases illustrate the fact that citizens in the late nineteenth and twentieth centuries were increasingly intolerant of odors and smells from MGPs, as well as smoke and stenches from other industries. But while the courts and regulatory bodies were willing to take limited action against the

23. Christine Meisner Rosen, "Regulating the New Industrial Air Pollution."

24. Letter, X. H. Goodnough, Chief Engineer, State Board of Health, to Dr. F. W. Draper, Chairman, Committee on Health of Towns of the State Board of Health, "Odors from the New England Gas and Coke Company," 30 July 1901, in A-MSBH. For a description of the New England Gas and Coke plant in Everett, the first in New England, see F. Schniewind, "The Everett Coke-Oven Gas Plant," 366-90.

25. Massachusetts Department of Health to the General Court, "Report of the Department of Public Health Relative to Causes of Offensive Odors Emanating from Industrial Processes in the Cities of Everett and Chelsea," 7 December 1932, in A-MSBH. There were also problems with the odors from the Lowell MGP mentioned above; see Safford, "Wastes from Lowell Gas Light Company's Yards," 172-77.

26. Massachusetts Department of Health to the General Court, "Report of the Department of Public Health Relative to Causes of Offensive Odors." In the case of Pottstown Gas Company vs. Murphy (39 Pa. 257 [1861]) - an appeal before the Pennsylvania Supreme Court in a case against the gas company for creating a nuisance-the attorney for the plaintiff argued that "a certain degree of offensive odour [sic] is unavoidably incident to the business, and must be endured by the public, or the business must stop." 
JANUARY

2014

VOL. 55 gas nuisance and the degradation of urban air quality, they were unwilling to demand strong measures on a consistent basis, reflecting the continued tension between industrial development and the urban environment. ${ }^{27}$

In addition to the gas nuisance affecting air quality, MGP operations frequently resulted in the pollution of groundwater supplying wells of nearby residences and businesses. ${ }^{28}$ The yards of gas works, which usually had earth surfaces, were commonly covered with oily and tarry deposits resulting, as one gas engineer noted, from the "improper disposal" of effluents or from leaks. ${ }^{29}$ Such wastes sank into the ground and often penetrated groundwater that supplied neighboring wells, contaminating water quality. Nuisance cases involving well pollution appeared through much of the industry's history. In 1861, for instance, in the case of Pottstown Gas Co. vs. Murphy, a hotel owner claimed that wastes from the gas company had polluted his well, making it unusable. The Supreme Court of Pennsylvania ruled that the gas company had committed a nuisance not only by permitting "fluids" to "percolate" from its works, but also by creating offensive smells. ${ }^{30}$ Courts in Illinois (1862) and Florida (1889) took similar positions in cases involving gas companies and private well pollution. ${ }^{31}$

An early-twentieth-century case involving well pollution pitted two major New Jersey industries against each other. The Ballantine Brewery Company of Newark used water from wells on its property to make beer, while the Public Service Corporation of New Jersey made coal and water gas on an adjoining site. Oil and coal gas tar from the MGP contaminated the groundwater that supplied the brewery's wells and it sued for damages. The New Jersey Supreme Court ruled against the gas manufacturer, who then appealed the case to the Court of Errors and Appeals. This court sustained the earlier judgment and ruled that the gas company had created a

27. The persistence of the smoke problem in Pittsburgh and other industrial cities, in spite of citizens' concerns, reflects the same situation. See Sherie R. Mershon and Joel A. Tarr, "Strategies for Clean Air," 145-73.

28. Leon J. Willien, "Disposal of Waste from Gas Plants," 363; AGA, "Report of 1920 Waste Disposal Committee," 413-64; Paul Hansen, "Disposal of Gas House Wastes" (American Gas Light Journal). Tarry wastes from MGPs are known as "dense nonaqueous phase liquids" (DNAPLs). They are immiscible fluids with a specific gravity greater than water and can present a serious, long-term source of continued groundwater and soil contamination. See Scott G. Hulling and James W. Weaver, "Dense Nonaqueous Phase Liquids."

29. "Pollution of Malden River," in A-MSBH; George C. Whipple, "Gas Wastes," 145-69; "The Disposal of the Waste Products of Gas Works," 434-37. Such groundwater pollution increased with the shift from coal to water gas.

30. See Pottstown Gas Co. vs. Murphy (39 Pa. 257 [1861]). The defendants were also found to be responsible for creating an odor nuisance.

31. See the Ottawa Gas Light and Coke Company vs. James Graham (28 Ill. 73-77 [1862]); Ottawa Gas Light and Coke Company vs. Darlin Thompson (39 Ill. 598-601 [1864]); and Pensacola Gas Light Company vs. Pebble, Supreme Court of Florida, 5 February 1889 (Southern Reporter 5, 593-97). See also Craig E. Colten, "A Historical Perspective on Industrial Wastes and Groundwater Contamination,” 215-28. 
nuisance and did not have the right to allow polluting material to "percolate through the soil and contaminate the well water of its neighbor." 32

The pollution of surface waters by MGP wastes was another frequent cause of citizens' complaints, lawsuits, and legislative action. Water-supply pollution could be the object of nuisance suits if a private injury could be identified. ${ }^{33}$ In 1856, a carpet manufacturer brought suit against the Auburn (New York) Gas Light Company, charging that the company allowed tarry and oily substances to flow from its site into the river from which the firm drew its process waters, thereby debasing its product. The lower courts held for the plaintiffs, as did the New York Supreme Court on appeal. In a significant early ruling regarding the pollution of streams, the Supreme Court held that no one had the right to corrupt "the waters of freshwater streams, so essential as they are to the health and comfort of man and beast, so indispensable to life, and for domestic, agricultural and manufacturing purposes." It found that the operation of the gas works created a private nuisance, and that the plaintiffs could seek damages from the gas firm. The court issued an injunction against the firm to cease polluting the river. ${ }^{34}$

During the latter half of the nineteenth century and the first decades of the twentieth, as regulatory authority expanded, issues relating to gas and other industrial wastes in waterways increasingly invoked a legislative rather than common-law response. ${ }^{35}$ Many of these issues related to the effects of the wastes on fish and shellfish, although water quality and despoliation of beaches were also matters of concern.

Fishing and shellfish-gathering were major industries in the United States and Great Britain during the nineteenth and early twentieth centuries. Early in the nineteenth, in England, the complaints of commercial fishermen over the injurious effects of gas wastes on fish brought legal and legislative responses. ${ }^{36}$ Similar complaints emerged two decades later in the United States, where fishing employed thousands, served as a common recreational sport, and provided a major source of protein. ${ }^{37}$ As industrialization advanced, fish and shellfish populations in rivers, bays, and estuaries dimin-

32. Ballantine, P. \& Sons vs. Public Service Corporation of New Jersey (76 N.J. 358 [1908]); Ballantine, P. \& Sons vs. Public Service Corporation of New Jersey (86 N.J. 331 [1914]). J. H. Shotwell, "Method of Purifying the Residuum of Gas Works before Allowing It to Pass Off into the Water," 134.

33. William J. Novak, The People's Welfare, 43-50, 217-33.

34. Carhart vs. Auburn Gas Light Company (22 N.Y. Barb. 297 [1856]), 311-12.

35. Stanley Montgomery and Earle B. Phelps, Stream Pollution, 7.

36. In Great Britain during the 1820s and later, Parliament enacted multiple pieces of legislation forbidding gas-house wastes in waterways in response to complaints about the state of the Thames River, including the Gasworks Clauses Act (1847), the Salmon Fisheries Act (1861), and the Rivers Pollution Prevention Act (1876). None of these acts was effectively enforced; see Tomory, "The Environmental History of the Early British Gas Industry, 1812-1830," 29-54.

37. Stephen C. Esser, "Long-term Changes in Some Finfishes of the Hudson-Raritan Estuary." 
JANUARY

2014

VOL. 55

ished, and fishermen and shellfish-gatherers targeted industrial pollution, and especially the manufacturing gas and petroleum industries, as the cause.

In response to these complaints, several state legislatures and city councils moved to regulate manufactured-plant-waste disposal. New York was first to act. In 1845, after 1,656 inhabitants of New York City petitioned the state legislature complaining about gas wastes in New York waters (Hallet's Cove specifically), the legislature approved an act forbidding the discharge of gas wastes into waters in Kings (Brooklyn), New York (Manhattan), and Queens counties-water where fishing and shellfish-gathering were important industries, as well as recreational activities. Violation of the law was a misdemeanor, but it did not specify any penalties. $^{38}$ The law was one of the first enacted by a state against an industrial pollutant, but it had little effect because of the absence of an enforcement mechanism. In 1882, the legislature passed a second statute forbidding the discharge of gas house wastes "into any public waters, river, or stream," this time confining the prohibition to New York County alone. Again, however, the legislation appeared to lack any enforcement teeth. ${ }^{39}$

Damages to New York 's extensive oyster industry, however, brought a more vigorous response. In the nineteenth century, oyster beds were found throughout much of the lower New York estuary, in locations like Jamaica Bay, Arthur Kill, Kill van Kull, and the New Jersey shore of the Hudson River. ${ }^{40}$ Believing that gas-house wastes were impacting the oyster industry, in 1873 the Brooklyn Board of Health prohibited their discharge into the city's streams, streets, or public places in order to protect the local oyster beds, approving the same ordinance several times during the following decades. Oystermen and shellfish merchants complained not only about manufactured gas pollution, but also about wastes from the petroleum and sugar refineries in New Jersey and New York. ${ }^{41}$

In 1886, responding to the protests, the state legislature moved to "protect" New York's oyster beds by banning the discharge of "sludge acid or other refuse matter" from oil refineries, sugar refineries, and manufactured gas works into New York waters. Enforcement provisions were included on this occasion, and the legislature appointed Joseph Mersereau, a Staten Island oyster merchant, as State Oyster Protector to investigate pollution sources. In his 1887 report, Mersereau singled out sludge acid from petroleum refineries and manufactured gas plants for the pollution, noting that "Gas-works have ... been a prolific source of trouble.... The refuse emit-

38. New York State Legislature, "Laws ... Passed at Sixty-Eighth Session."

39. New York State Legislature, "Laws ... Passed at the One Hundred and Fifth Session.”

40. David R. Franz, "An Historical Perspective on Mollusks in Lower New York Harbor"; Mark Kurlansky, The Big Oyster, 175-76.

41. "Sanitary Ordinances"; "Protecting Sheepshead Bay"; "State Protection for Public Waters." 
ted there ... being very similar to the refuse from oil refineries, and no less disastrous to oyster interests." 42

Fish and shellfish populations in New York Harbor continued to decline, and in 1909 and 1912, commercial fishing interests convinced the New York legislature to strengthen the statute prohibiting the discharge of gas wastes into state waters by making it a misdemeanor. ${ }^{43}$ Other states followed New York's lead, enacting legislation that was consistent with other enactments in the conservation movement of the early twentieth century. ${ }^{44}$ In New Jersey, for instance, where oyster-taking and fishing were extensive industries, the legislature enacted statutes in 1903 and 1909 forbidding the placing of "deleterious substances," such as coal tar, gas-house refuse, and other manufacturing wastes destructive of fish life, into state waters. Between 1912 and 1917, California, Delaware, Indiana, Ohio, and Pennsylvania all enacted similar laws against the disposal of gas-house wastes into waterways, sometimes specifying specific streams. ${ }^{45}$

The state of Massachusetts pioneered attempts to protect its waters from pollution and, although MGP wastes were not specifically mentioned in legislation, in 1866 and 1877, the State Board of Health reported their injurious effects on fish and stream quality. ${ }^{46}$ In the early twentieth century, the board's successor, the Department of Health, mandated ceaseand-desist orders against the Malden-Melrose Gas Light Company, the Brockton Gas Works, the New England Gas and Coke Works, and the

42. Mersereau asked the gas companies to stop discharging wastes into the East River. When they refused, he presented his pollution evidence to the grand jury. The grand jury brought indictments against the gas firms, but a technicality freed them from trial. In his 1887 report, Mersereau noted that they continued allowing "their refuse to flow into the river" (New York State Assembly, "Report of J. W. Mersereau, State Oyster Protector"). For the impact of gas wastes on oysters, see Philip H. Mitchell, "The Effect of Water-Gas Tar on Oysters"; and Thurlow C. Nelson, The Conservation of New Jersey's Oyster Industry. See also Andrew Hurley, "Creating Ecological Wastelands"; Bonnie J. McCay, "Oysters, Public Trust, and the Law in New Jersey"; and Christine Keiner, The Oyster Question.

43. Section 1759 of the New York State Penal Code of 1909, chap. 40; Laws Passed at the One Hundred and Thirty-sixth Session (1913), chap. 508.

44. Samuel P. Hays, Conservation and the Gospel of Efficiency.

45. These statutes are recorded in Montgomery and Phelps, Stream Pollution. The records of the U.S. Bureau of Fisheries also contain several complaints concerning the effect of gas wastes on fish. See Adrian Thomas, Fish Pathologist to Dr. R. E. Cohen, Bureau of Fisheries, "Report on Conditions at Richmond, Virginia and Vicinity Concerning the Pollution of the James River as Affecting Fishery Resources," 21 June 1916, RG 22, in Archives of the U.S. Fish and Wildlife Service, National Archives, Washington, D.C. (hereafter A-USFWS).

46. Massachusetts Commissioners on Fisheries and Game, "Report to the Senate Concerning Obstructions to the Passage of Fish in the Connecticut and Merrimack Rivers" (1866), 14-17. In 1877 the Massachusetts State Board of Health noted that in the Nashua River Basin, "tarry and ammoniacal [sic] refuse" wasted by MGPs "mingles slowly with water, and is noticeable at a long distance from its point of discharge"; see Massachusetts State Board of Health, "The Pollution of Streams" (1877), 43. 
JANUARY

2014

VOL. 55
Salem MGP for polluting water bodies with their wastes. Other MGPs were found to be responsible for cove and beach pollution. ${ }^{47}$

The state of Illinois also attempted to reduce industrial, as well as other, sources of pollution to its rivers to protect its commercial fisheries and drinking water. In 1911, the legislature formed the Illinois Rivers and Lakes Commission, and in 1913 gave it the power to subpoena witnesses and mandate cease-and-desist orders. ${ }^{48}$ In its annual reports, the commission frequently noted that wastes from MGPs damaged state fish populations and that it had issued orders to halt the pollution. ${ }^{49}$ In 1927, it published a survey, Pollution of Streams in Illinois, which reported that forty-seven gas-manufacturing plants were polluting the streams on which they were located. ${ }^{50}$

State and federal government agencies also conducted scientific studies of the injurious effects of industrial and gas-house wastes on fish and oysters. In 1907, for instance, the U.S. Bureau of Fisheries performed a bioassay on fish and industrial wastes that found gas-plant tar wastes to be especially poisonous because they were more difficult to dilute than other wastes. ${ }^{51}$ In 1917, Victor Shelford of the Illinois State Laboratory of Natural History performed a bioassay on the effect of coal-tar wastes on different species of fish in Illinois streams, concluding that coal-gas products were so dangerous to fish that they should be kept out of bodies of water "even if the wastes had been treated." ${ }^{2}$ A New York state biologist offered confirmation of these results in 1918 when he observed: "Many observers have seen a beautiful little brook rich in fish and other aquatic life transformed into a barren, unsightly, stinking stream, merely by the addition of wastes from a small town gas plant." 53

47. "Pollution of Malden River," 113-14, in A-MSBH. In a 1908 report, the Massachusetts State Board of Health noted that the banks of the Malden River below the works of the Malden-Melrose Gas Light Company were covered with tar and oil primarily from overflow of the water seals of the gas holders.

48. Craig E. Colten, "Illinois River Pollution Control." Colten notes that the commercial fisheries expanded greatly up to 1908, and then sharply declined. The loss of wetlands and spawning areas played an important role in reducing the fisheries, but industrial pollution was undoubtedly a factor.

49. State of Illinois, Annual Reports of the Rivers and Lakes Commission of Illinois, 1913-14, 1915, 1916, 1924-25, 1925-26, 1927-28, 1930-31. The commission wrote that the gas wastes impacted the "more valuable fishes."

50. State of Illinois, Division of the State Water Survey, Pollution of Streams in Illinois. The division surveyed 884 towns in twenty-one drainage basins.

51. M. C. Marsh, "The Effects of Some Industrial Wastes on Fishes," 337-48. Reports from the U.S. Fish Commission in 1878 and 1885 and the Bureau of Fisheries in 1921 all emphasized the central role of gas plants in contaminating fisheries. See J. S. Gutsell, Danger to Fisheries from Oil and Tar Pollution of Waters; and Marshall McDonald, "Report on the Pollution of the Potomac River" (1885), in A-USFWS.

52. Victor E. Shelford, "An Experimental Study of the Effects of Gas Waste upon Fishes," 381; Edwin B. Powers, The Goldfish as a Test Animal in the Study of Toxicity.

53. Henry B. Ward, Stream Pollution in New York State, 32-34. For more on the haz- 
Concern over the impacts of MGP and industrial wastes on drinkingwater supplies developed slowly compared to concerns over their effects on fish. It was not until the early 1920s, for instance, that the American Water Works Association appointed a Committee on Industrial Wastes in Relation to Water Supply. In 1922, this committee reported that industrial pollutants had damaged at least 248 water supplies in the country. Waterquality specialists considered phenol wastes from manufactured gas and by-product coke plants to be among the most serious pollutants. ${ }^{54}$ Municipalities began chlorinating their water supplies after 1908 in order to control waterborne infectious disease, but chlorine interacted with phenol wastes from MGPs, producer gas units, by-product coke ovens, and tar factories, giving the water "disagreeable" tastes and odors. Water-quality officials worried that if water became unpalatable because of taste and odor problems, populations might drink unprotected supplies, exposing themselves to waterborne infectious disease. ${ }^{55}$

By the early 1920s, more than fifty cities in the states of Indiana, Illinois, New York, Ohio, Pennsylvania, West Virginia, and Wisconsin were experiencing problems with the phenol pollution of water supplies. In 1929, A. R. Powell of the Koppers Company-a major factor in the coalcarbonization industry-served as chairman of the American Gas Association (AGS) Committee on Disposal of Waste from Gas Plants. Powell noted that the phenol problem was "the most important waste disposal problem before the American gas industry today." 56

Another by-product of the gas-manufacturing process that affected water quality was the formation of emulsions of oil tar and process water during the production of carbureted water gas. These emulsions resulted from several causes, including the use of bituminous coal, the timing of blows, and the faulty cracking of the oil. Their disposal was problematic; in 1901, for instance, at an American Gas Light Association conference, a gas engineer observed that MGPs had been disposing of their emulsions by

ards to fish, see State of New York Conservation Commission, Thirteenth Annual Report for the Year 1923; and M. M. Ellis, "Detection and Measurement of Stream Pollution."

54. "Progress Report of the Committee on Industrial Wastes in Relation to Water Supply"; "Progress Report on Recent Developments in the Field of Industrial Wastes in Relation to Water Supply."

55. The objectionable wastes came from ammonia, benzol, and naphthalene stills and tar separators.

56. A. R. Powell, "Report of Subcommittee on Disposal of Waste from Gas Plants," 929. The situation was especially severe in the cities of the upper Ohio River basin, where nineteen by-product coke plants were located. Because this was an interstate problem, the U.S. Public Health Service convened conferences in 1923 and 1924 involving the health departments of Pennsylvania, West Virginia, and Ohio, resulting in formation of the Tri-State Agreement to develop uniform policies of control and legislation. See R. D. Leitch, "Stream Pollution by Wastes from By-Product Coke Ovens"; "Progress Report of the Committee on Industrial Wastes in Relation to Water Supply"; and Joel A. Tarr, "Searching for a Sink for an Industrial Waste." 
JANUARY

2014

VOL. 55

running them "into some convenient sewer, river or bay," but that now they faced "the efforts of civil authorities to maintain the purity of water in rivers and harbors." Other means of disposal had to be found, as well as ways to capture a salable tar by-product. ${ }^{57}$ During the first decades of the century, engineers succeeded in reducing emulsions, but as water gas production grew, the emulsion problem increased. Complicating the issue was industry use of heavy and cheaper oils in the cracking process due to gasoline industry competition for lighter oils. Emulsions remained a problem for the manufactured gas industry for the remainder of its history. ${ }^{58}$

\section{By-products, Wastes, and Industry Reaction to Pollution}

The manufactured gas industry, as has been noted, produced a variety of by-products, including tars, oils, sludges, emulsions, ammonia, spent limes and iron oxides, and cyanide, as well as ash, clinker, and coke. These by-products usually resulted from normal operations and occurred at different stages of the production process; changes in technology or fuels could also produce by-products with negative effects, such as emulsions, while markets could develop for by-products that formerly had limited value, such as tar. ${ }^{59}$

Whether or not the by-product became a "waste" depended on possible use for the material and market demand; if demand fluctuated or when there were no markets, issues of disposal or storage arose. In the absence of a market, by-products like coke and tar might be used as fuel at the plants, while other wastes, such as clinkers, lime, woodchips, or iron oxide from the purifying boxes, sometimes mixed with tar, were frequently buried in landfills or in pits on-site. In numerous cases, manufactured gas plants dumped by-products like tar and ammonia in waterways either onsite or off-, often creating major environmental problems. ${ }^{60}$

57. Wm. E. McKay, "Tar and Water from Water-Gas"; James S. Mellhenny, "Removal of the Last Traces of Oil and Tar from Water of Condensation"; Leon J. Willien, "Water Gas Tar Emulsions"; H. K. Seeley, "Report of the Subcommittee on Water Gas Tar Emulsions," 1084, and "Report of the Subcommittee on Water Gas Tar Production"; E. D. Carswell, "Tar Emulsion."

58. See, for instance, Jerome J. Morgan and Charles F. Stolzenbach, "Heavy Oil Tar Emulsions in the Water Gas Process, Pt. I" and "Heavy Oil Tar Emulsions in the Water Gas Process, Pt. II"; and F. B. Parks, "Carbureted Water Gas from Heavy Oils with Related Tar and Emulsion Problems."

59. For by-products, see Munroe, "By-Products in Gas Manufacture"; R. S. McBride, "Manufactured Gas and Byproducts in 1920"; and Pierre Desrochers, "Victorian Pioneers of Corporate Sustainability."

60. Hatheway quotes Chicago gas engineer George Shepard Page as saying that in 1881, lime was often disposed of through dumping; see Hatheway, Remediation of Former Gas Plants and Other Coal-Tar Sites, 554. See also Brian L. Murphy, Tarn Sparacio, and Walter J. Shields, "Manufactured Gas Plants-Processes, Historical Development, and Key Issues in Insurance Coverage Disputes." 
Up until the end of World War I, the industry paid limited attention to waste-disposal issues. The great majority of papers presented at conferences and published in proceedings or journals dealt with technical issues and operational problem-solving, innovations in consumer products, questions of regulation (price and quality), marketing, and publicity. Although the industry had become a frequent target of nuisance suits (reported in the major gas journals) and several states and municipalities had statutes forbidding the discharge of gas wastes into streams, penalties and sanctions were normally too weak to change industry behavior. ${ }^{61}$

In a survey of the technical literature from approximately 1880 to 1919 , this author has identified only four articles that dealt primarily with issues of waste disposal and pollution. These articles, all by engineers, focused on both on-site and off- pollution and also raised issues regarding nuisance suits and legislation.

In 1899, for instance, Frederick Shelton, a Philadelphia gas engineer from the United Gas Improvement Company (UGI), presented a paper at the 29th Annual Meeting of the Association of New England Gas Engineers titled "The Nuisance Question in Gas Works," which was later published in the industry journal Progressive Age. Shelton warned of the necessity of avoiding "any question of nuisance" because of possible court action. He specifically noted that MGP contamination of wells, pollution of protected streams, and the emission of fumes that destroyed vegetation or that produced noxious vapors could provide "sufficient ground for complaint and legal action." Shelton warned that given this direction by the courts, "a gas company must conduct its business and operate its plant in such a way as will not injure its neighbors." The published discussion that followed the paper made it clear that the problems Shelton cited were familiar to his audience of gas engineers. ${ }^{62}$

A second significant paper on waste-disposal issues, revealing in its discussion of on-site pollution, was Arthur Safford's 1907 article "Wastes from Lowell Gas Light Company's Yards," published in the Journal of the Association of Engineering Societies. In the early twentieth century, "fearful odors" plagued Lowell, Massachusetts, and the city engineer claimed that they originated from the Lowell Gas Light Company. The firm proceeded to hire Safford, a noted engineer, to see if he could identify their exact

61. An unsigned article published in 1906 in the industry journal Progressive Age summarized the main points of a U.S. Geological Survey report on water supply and riparian rights; it noted that it would be of "interest [to] those of our readers who have been accused by town authorities of polluting streams." The report warned that riparian owners should "refrain from every use in manufacturing" that would pollute or reduce the quality and quantity of water to downstream users. See "Pollution of Streams," 73940; and E. B. Goodell, A Review of the Laws Forbidding Pollution of Inland Waters in the U.S. U.S.G.S. Water Supply.

62. Frederick H. Shelton, "The Nuisance Question in Gas Works" (1899) and "The Nuisance Question in Gas Works” (1900). 
JANUARY

2014

VOL. 55 source. Safford found that the site contained a number of older structures and pits that leaked tar into the ground; he estimated that the site contained at least 1.6 million gallons "of liquid of an objectionable character" and made a number of technical recommendations to eliminate the odors. While the company made some improvements, it appears that they were limited, since State Department of Health complaints about its waste-disposal practices continued during the following years. ${ }^{63}$

The most thorough investigation of the waste-disposal problems of the manufactured gas industry at the beginning of the twentieth century was Harvard University sanitary engineer George Whipple's study of "Gas Wastes," commissioned in 1907 by the New Jersey Sanitary Commission. The commission published it in its 1908 report, and Engineering Record summarized it in a major article in the same year. ${ }^{64}$ Whipple identified a number of problems stemming from gas wastes, including surface- and groundwater pollution, clogging of sewers, and interference with sewagetreatment processes. He noted, as had Safford, the sloppy conditions that characterized many plant sites, resulting in the pollution of land, groundwater, and adjacent watercourses. Gas-industry operatives, he said, did not fully appreciate the "objectionable results of discharging unpurified liquid gas wastes into sewers and water courses"-implying that if they did, they would not commit the polluting acts. He observed that there were "fairly simple and effective" means of treating wastes, and that the "material saved and the relief from complaints and damage suits" that would result from their application would cover most of their costs. ${ }^{65}$

In 1916, sanitary engineer Paul Hansen of the Illinois Water Survey published an article on the "Disposal of Gas House Wastes" in American Gas Light Journal that repeated many of the same concerns as Shelton's and Whipple's. He warned of "tarry deposits that polluted the soil, contaminated wells, migrated into cellars," and had a "highly toxic" effect on fish. He maintained, as had Whipple, that the pollution problems caused by gas wastes could be avoided with proper treatment, and repeated these warnings in a paper delivered at the 1916 conference of the Illinois Gas Association. ${ }^{66}$

63. Safford, "Wastes from Lowell Gas Light Company's Yards," 169-83. The MGP continued to be a source of pollution problems, and in 1908, the Massachusetts State Board of Health complained that its wastes were polluting the Malden River; see "Pollution of Malden River," 135-38, in A-MSBH. In 1988, the wastes on this site became the subject of litigation; see Jan Richard Schlichtmann, The Known and Present Danger. I am indebted to Patrick Malone for bringing this report to my attention.

64. The (George C.) Whipple Report, "Gas Wastes," was included in the New Jersey State Sewerage Commission's Report of the State Sewerage Commission to the [New Jersey] Legislature of 1908; see also "The Disposal of the Waste Products of Gas Works," 434-37.

65. Whipple, "Gas Wastes."

66. Hansen, "Disposal of Gas House Wastes" (American Gas Light Journal) and "Disposal of Gas House Wastes" (Proceedings of the Illinois Gas Association). Hansen became the chief sanitary engineer of the Illinois Department of Health; see Hatheway, Remediation of Former Gas Plants and Other Coal-Tar Sites, 1297. 
As indicated by the limited number of articles in the trade literature focusing on the issue, the industry seemed to take little systematic notice of the pollution caused by its waste-disposal methods in spite of nuisance suits and state and municipal legislation. ${ }^{67}$ This situation changed with the coming of World War I. During and immediately after the war, industrial wastes and oil spills from both off- and onshore sites created serious waterpollution problems, damaging shellfish and fish stocks and despoiling beaches in several states, including New Jersey, New York, and Pennsylvania. Commercial and recreational fishermen, conservation groups, and chambers of commerce and tourist officials demanded an investigation of the contamination. In the early 1920s, congressional representatives introduced several bills to control oil, gas-house wastes, and other types of industrial pollution. ${ }^{68}$

In 1921 and again in 1924, subcommittees of the House and Senate conducted hearings on the subject of the pollution of navigable waters. The committees were primarily concerned with oil (sludge) in harbor and seacoast waters originating from both off- and onshore sources, but considered industrial pollution of all types, including MGP wastes. In 1924, for instance, Captain J. C. Fremont of the U.S. Navy-the New York Harbor supervisor-testified about pollution conditions in the harbor that were violations of the 1888 U.S. Rivers and Harbors Act forbidding "obstructive and injurious deposits." ${ }^{\prime 9}$ Fremont presented the committee with a list of

67. An editorial in the 16 January 1883 American Gas-Light Journal admonished MGP operators to "[a]lways keep your works in the best possible condition, for then and only then can you hope to obtain good results. To so act is economy in its truest sense" (qtd. in Hatheway, Remediation of Former Gas Plants and Other Coal-Tar Sites, 552).

68. For these complaints, see U.S. Congress, Pollution of Navigable Waters. See also U.S. Fish and Wildlife Service, "Memorandum Regarding Sources and Effects of Oil Pollution" and "Memorandum on Detrimental Effects of Oil Pollution on Bathing Beaches, etc.," box 1, in A-USFWS. These memoranda appeared to have accompanied correspondence from Sedley H. Phinney, Secretary, National Coast Anti-Pollution League of America, to H. F. Moore, Acting Commissioner, Bureau of Fisheries, Department of Commerce, 14 September 1923, box 1, in A-USFWS. The comprehensive study by Joseph A. Pratt, Black Waters, examines the controversy over oil pollution and the attempts to regulate it in detail. I am indebted to Professor Pratt for making available to me various records of the U.S. Army Corps of Engineers from the National Archives concerning the oil crisis, and for his continued encouragement regarding this research.

69. While there was only limited federal legislation available until the 1960s regarding pollution, in 1886 and 1888, the U.S. Congress approved an act forbidding disposal of "any ballast, stone, slate, gravel, earth, slack, rubbish, wreck, filth, slabs, edgings, sawdust, slag, or cinders, or other refuse or mill-waste of any kind into New York Harbor." The 1888 act forbade "obstructive and injurious deposits" into the harbor and banned the discharge of "refuse, dirt, ashes, cinders, mud, sand, dredgings, sludge, acid, or any other matter of any kind, other than that flowing from streets, sewers, and passing there from in a liquid state." See 24 Stat. 329 (1886) and 384 U.S. 224, 227 (1888). The 1890 and 1894 U.S. Rivers and Harbors Acts (25 Stat. 209) contained similar provisions in regard to waste disposal that would "tend to impede or obstruct navigation" in the harbor. 
JANUARY

2014

VOL. 55

industrial plants responsible for violations of the act, including a number of New York-area MGPs, such as Brooklyn Borough Gas Company, Brooklyn Union Gas, Mutual Gas Company, and the West End Gas Works. ${ }^{70}$ Other investigations by the U.S. Army Corps of Engineers and the U.S. Bureau of Mines of oil pollution, sometimes in collaboration with industry groups, confirmed the important role of MGP wastes, as well as oil, in adding to harbor and waterway contamination in other ports. ${ }^{71}$

\section{The AGA Confronts Environmental Pollution}

In 1918, the AGA was formed by a consolidation of the American Gas Institute and the National Commercial Gas Association. It described itself as "a general clearing house of gas information." 72 Among the AGA's initial standing committees was the Committee on Disposal of Waste from Gas Plants-industry recognition that a problem existed. The committee's reports during the 1920s constitute an extensive record of the industry's waste-disposal problems, and they were presented at the AGA annual conventions and summarized in industry journals. Its creation was stimulated by rising demands for federal regulation of industrial pollution (especially oil), and was an attempt at self-regulation by the industry in order to avoid government intervention in its waste-disposal practices. The American Petroleum Institute (API), the national representative of the petroleum industry, was following a similar strategy. ${ }^{73}$

70. For these complaints and a list of MGPs violating the 1894 act, see U.S. Congress, Pollution of Navigable Waters and "Statement of Capt. J. C. Fremont." The 1899 Rivers and Harbors Appropriation Act (the "Refuse Act") applied the restriction regarding dumping more broadly to "any navigable water of the United States, or into any tributary of any navigable water."

71. The report on "Pollution by Oil of the Coastal Waters of the United States," a survey conducted in 1923 by the American Petroleum Institute (API) and the American Steamboat Owner's Association, concluded that "gas plants as a whole must be looked upon as an important source of oil pollution." The report also noted that the industry appeared "to recognize the importance of the oil pollution problem," since the AGA had appointed a waste-disposal committee. The joint committee noted that the pollution by the gas industry appeared to be "a difficulty associated more with the management and operating force than an inability to construct effective separating devices." See "Pollution by Oil of the Coastal Waters of the United States," prepared by the U.S. Bureau of Mines in cooperation with the API and the American Steamship Owner's Association, September 1923, Archives of the U.S. Army Corps of Engineers (hereafter A-USACE), National Archives, Washington, D.C. For the U.S. Army Corps of Engineers' investigations after 1924, see R. Taylor, Major General, Chief of Engineers, "Pollution of Navigable Waters and Nonnavigable Tributaries Thereof" to the Secretary of War, 4 June 1926, file 7235 (in A-USACE).

72. Louis Stotz and Alexander Jamison, History of the Gas Industry, 122-29; AGA, AGA: What It Is-What It Does.

73. Joseph A. Pratt, "Creating Coordination in the Modern Petroleum Industry"; Castaneda, Invisible Fuel, 8-30. 
The first chair of the AGA committee was Leon Willien, an MITtrained chemical engineer employed at the time by the Charles $\mathrm{H}$. Tenney Company in Boston, a gas-firm holding company. Willien served as chair of the waste-disposal committee in 1919,1920 , and $1923 .{ }^{74}$ He set out the reasons for the committee's creation in his first report in 1919, and also in several articles he wrote for industry journals. In his "To Avoid Stream Pollution," published in The Gas Record in October 1920, for instance, he noted that "public authorities" were increasingly aware of stream pollution, and that "gas plants are receiving their share of the blame for such pollution." "Sometimes," he added, "it is just and sometimes unjust," and the committee would attempt to determine the validity of the charges. ${ }^{75}$ The committee proposed not only to collect data on "the various systems for the disposal of waste in coal, water gas and coke oven plants throughout the country," but also "to help firms experiencing waste disposal problems solve them."

In his 1920 annual report, Willien listed in detail the "injurious effects which are attributed to the waste from gas plants: driving away fish and damaging oyster beds ... damage to paint on boats ... objectionable odors ... pollution of wells ... deposits in sewerage systems ... [and] pollution of drinking water supply where water is chlorinated." He warned that leaks in gas, tar, and oil lines "could pollute groundwater and streams," and that small- and medium-sized water gas plants often allowed "light oils and tar emulsions to escape in appreciable quantities."77 After discussing the different types of MGP pollution, he listed forms of treatment and disposal that could be followed. ${ }^{78}$ Further reports by the AGA waste-disposal committee in the 1920s identified other types of problems, including the

74. Willien became the associate director of the Institute of Gas Technology; he was the recipient of the AGA's two top awards. See "Willien," 44.

75. In an insert to the article, the journal's editor added the comment: "So many serious conditions have developed from improper handling of such wastes that it behooves every gas company to give careful attention to methods for disposal." See Leon J. Willien, "To Avoid Stream Pollution."

76. Leon J. Willien, "Report of the Committee on Disposal of Waste from Gas Plants." Two other papers were given by members of the AGA Waste Disposal Committee at the 1919 convention, one on the taste-and-odors problems caused by manufactured gas wastes, and the second one on waste disposal in small streams near parks. See, respectively, R. B. Brown, "Disposal of Wastes from Gas Plants," and L. R. Dutton, "The Disposal of Waste Water from Water Gas Plants on Streams Adjacent to Parks."

77. See the comments after Willien's report, "Report of the Committee on Disposal of Waste from Gas Plants," in AGA Proceedings, 460-63.

78. The AGA Waste Disposal Committee met several times during the 1920s, often focusing on the problem of tar emulsions from the water gas process; see Leon J. Willien, "Report of the Committee on Waste Disposal from Gas Plants," 501. A 1927 AGA committee report noted that emulsions were "useless" and could be run into sewers, except "that they seriously pollute streams, lakes, etc." The committee chair, H. K. Seeley, recommended various means of treatment, but also advised that the best strat- 
JANUARY

2014

VOL. 55

dumping of wastes like iron oxides, tar decanter settlings, and saturator sludges. ${ }^{79}$

In 1930, the Pacific Coast Gas Association (PCGA), emulating the AGA, formed a committee on Gas Plant Waste Disposal to consider that region's problems and the special difficulties created by its dependence on oil rather than coal as a feedstock. N. H. Wardale of the Portland Gas and Coke Company, chair of the committee, used the same rationale as Willien had in 1919 to explain the purpose of the PCGA committee's creation: namely, that since the public and health authorities were becoming more interested in air- and water-pollution prevention, the industry had to investigate its own waste-disposal practices in order to avoid further regulation. ${ }^{80}$

In order to secure a database on waste-disposal methods, the committee sent out a questionnaire to a hundred gas companies throughout the nation, receiving replies from fifty-seven. These surveys provide an informative set of data regarding MGP waste disposal, as well as various remediation methods. ${ }^{81}$ (Not all answers are recorded here, and the numbers reported are meant to reflect a summation of questions and responses.)

More than half the firms (38) that replied reported that they had to comply with strict water-pollution ordinances, although a number of them (27) reported either no regulations at all or a lack of strict enforcement. Seven companies reported discharging their wastes into water used for "boating, bathing, fishing, and drinking," and fifteen discharged into water used for everything but drinking. Most firms (34) used some sort of treatment before discharging wastes, including oil wastes and ammonia, to sewers, although a small number (6) reported discharging to sewers and streams with no treatment at all. Twelve firms reported discharging their wastes into streams that were already badly polluted. Twenty-four of the firms that responded reported using spent oxide from gas purifiers for fill on their own property or giving it away; thirteen hauled it to the city dump; and one company dumped it in the river "at flood time." Concerning smoke "nuisances," twenty-five reported that they did not have to comply with smoke ordinances, while only thirteen had to follow strict compliance.

The questionnaire asked about the most effective means of treating wastes, with twenty-one companies recommending separation and filtration, and the remainder reporting other methods. The report on the survey also noted, as Powell had in 1929, that phenol in liquors from ammo-

egy was to prevent their formation entirely. See Seeley, "Report of the Subcommittee on Water Gas Tar Emulsions."

79. Powell, "Report of the Subcommittee on Disposal of Waste from Gas Plants." The Koppers Company had developed a technique to treat these wastes.

80. N. H. Wardale, "Gas Plant Waste Disposal," 363. For a study of MGPs in California, most of which used oil gas rather than coal, see Allen W. Hatheway, "Manufactured Gas in California, 1852-1940."

81. Wardale, "Gas Plant Waste Disposal." 
nia stills produced the most "serious condition from gas plant waste," and recommended various strategies to deal with it. In a section on water pollution, the report warned that gas companies located on streams that supported fish life had to treat or remove dissolved compounds with a high oxygen demand and to eliminate tar, oil, and solid matter. The report also noted that state health authorities were attempting to make sewage treatment compulsory, and that gas companies should treat their wastes before stream disposal or disposal to a sewage-treatment plant. $^{82}$

This survey provides the most thorough review of gas waste-disposal methods published at the time. ${ }^{83}$ The AGA waste-disposal committee, although it did discuss various waste-disposal practices, never attempted such a comprehensive review. In the 1930s, however, neither the AGA nor PCGA waste-disposal committees produced substantive reports, although similar problems remained. ${ }^{84}$ In 1949, the AGA created a new Joint Committee on Waste Disposal consisting of twenty-six industrial representatives, but it never held investigations comparable to those of the 1920s or ones similar to the PCGA survey in 1930. AGA subcommittees on waste disposal met several times again during the 1950s, but only the titles of papers presented were reported in its proceedings. Whether this limited approach was a result of a concern over adverse regulation is unclear. ${ }^{85}$

82. Ibid.; the committee acknowledged that the control of smoke was more difficult than dealing with other wastes.

83. Ibid.

84. The persistence of pollution problems from MGPs wastes is reflected, for instance, in the reports of the Minnesota Department of Health and the Minnesota Commissioner of Game and Fish during 1928 to 1934 regarding river pollution, and the "Minutes of the Pennsylvania Sanitary Water Board" from 1923 through the 1930s. See Minnesota Department of Health and Minnesota Commissioner of Game and Fish, "Report on the Investigation of the Pollution of the Straight and Cannon Rivers" (192830), 1, 4, 16, 19, and Minnesota Department of Health, "Report of the Investigation of the Cedar River . . in Collaboration with the Division of Game and Fish" (1930-32), 18-19, in Archives of the Minnesota Department of Health and the Minnesota Commissioner of Game and Fish, State Archives, Minneapolis; and the Archives of the Pennsylvania Sanitary Water Board, State Archives, Harrisburg.

85. At the initial meeting in 1949, W. B. Hart of the Atlantic Refining Companya prominent writer on petroleum-industry waste-disposal issues-and L. F. Warrick, chief of the Technical Service Branch, Public Health Service Division of Water Pollution Control, made presentations on stream-protection, waste-management, and water-pollution regulations. Neither specifically discussed MGP waste disposal. See, respectively, Hart, "Stream Protection and Management"; and Warrick, "Stream Protection and Management." 
The Shift from Manufactured to Natural Gas: The Decommissioning of Manufactured Gas Facilities and the Industry's Environmental Legacy

Natural gas is a substance that occurs in nature, as opposed to manu-

JANUARY

2014

VOL. 55 factured gas; both are composed of hydrocarbons, but they differ in heating value, as noted earlier. Natural gas is not distributed evenly throughout the environment, and well into the twentieth century, limitations in pipeline technology restricted its availability for domestic and industrial use in cities that were relatively close to the gas fields. ${ }^{86}$

In the first decades of the twentieth century, major natural gas discoveries were made in the American Southwest, but gas from these fields was initially flared because of the absence of nearby markets. During the 1920s and '30s, however, improved technology made it possible for utilities and pipeline companies to construct pipelines ranging from 200 to over a thousand miles in length and thus some urban markets were supplied. ${ }^{87}$ But it was not until after World War II that natural gas reached large cities in the mid-Atlantic region, such as New York and Philadelphia. This development was made possible by the conversion to natural gas of two pipelines-Big Inch and Little Inch-built by the federal government during the war to provide oil to East Coast cities. ${ }^{88}$

When gas reached an urban market, a major transition needed to take place between the manufactured gas distribution system and the new natural gas supplies. Conversion to natural gas as a fuel was unusual, in that the gas could be circulated in the same distribution system and consumed by the same appliances used by manufactured gas. However, the different Btu

86. The Fredonia New York Gas Light Company, the nation's first natural gas company, was formed in 1858 to light homes and businesses. In the late nineteenth and early twentieth centuries, there were four regions where natural gas was piped in for use in cities: western Pennsylvania and West Virginia; northern and central Indiana; locations around Los Angeles, including the San Joaquin Valley; and eastern Kansas. See Stotz and Jamieson, History of the Gas Industry, 67-73.

87. Before 1920, seamless-tube mills seldom produced pipe over six inches in diameter, and the longest pipelines were just less than 200 miles. See John H. Herbert, Clean Cheap Heat, 35-51. For a study of the adoption of natural gas in Denver and Kansas City, see Mark H. Rose, Cities of Light and Heat. The Great Depression and World War II slowed down pipeline construction, but in 1944, the Tennessee Gas Transmission Company completed a 1,265-mile pipeline from the Texas Gulf Coast to West Virginia as part of a wartime push to replace diminished Appalachian supplies. See Christopher J. Castaneda, Regulated Enterprise, 16-65; and Arlon R. Tussing and Connie C. Barlow, The Natural Gas Industry, 204-5. Congress passed the Public Utility Holding Company Act (PUHCA) in 1935, and the Natural Gas Act in 1938. PUHCA forbade large gas-distribution companies from owning and controlling both production and pipelines companies; the Natural Gas Act related to rates, service, and supply. See Castaneda, Regulated Enterprise, 26-30.

88. Christopher J. Castaneda and Joseph A. Pratt, Texas to the East; Tussing and Barlow, The Natural Gas Industry, 45-51. 
ratings of the gases negated the possibility of substituting the natural for the manufactured gas without gas-main and -appliance adjustments. Utilities faced major organizational tasks of conversion and adjustment from manufactured to natural gas, and the AGA created committees to study these issues. In 1931, for instance, an AGA subcommittee issued a report on "The Study of Factors Involved in Change-over from Manufactured to Natural Gas," concluding that compared to manufactured gas, natural gas presented fewer hazards. Utilities communicated extensively with one another about the conversion process and the pitfalls to be avoided. ${ }^{89}$

The shift to natural gas required the manufactured gas industry to decommission its older technologies. In a 1990 document, the Massachusetts Department of Public Utilities summarized the steps usually taken: "Decommissioning consisted of razing the above-ground structures to grade and using demolition rubble to fill in resulting holes. . . . Belowground tanks and pipes were purged of gas and left in the ground... . Cinders and tar liquids were disposed of on-site, and spent oxides were disposed of both on-and-off-site." 90 According to one environmental engineer whose firm was involved in MGP site-remediation: "Inappropriate demolition of manufactured gas plant (MGP) sites may leave a continuing legacy in the environmental records." He noted that on the MGP sites remediated by his firm, much of the contamination arose from on-site disposal operations or from spills and leaks during gas operations. ${ }^{91}$

The legacy of extensive contamination at these sites suggests that the industry paid limited attention to the need for thorough remediation. This author, for instance, could find no articles in the engineering literature during the period 1930-60 (the years of most conversions from manufactured to natural gas) that dealt with the steps needed to be taken in the decommissioning process. The literature discussed neither issues pertaining to site cleanup, nor explored the types of remediation and protections for groundwater and soils that might be taken when the sites were cleared. The lack of this kind of literature suggests that decommissioning, as previ-

89. Engineers and managers had to decide whether to use natural gas or natural gas mixed with manufactured gas. Some utilities used the natural gas to enrich manufactured gas, but others shifted entirely to natural gas, usually to avoid the necessity of adjusting gas appliances twice. In many cases, utilities kept their gas-making technology for emergencies and peak shaving purposes. See, for example, H. C. Abell, "Changing Over a City's Gas Supply"; Arthur H. Anderson, "Natural Gas Comes to Detroit"; "Con Edison Turns on the Gas"; and David Grozier, "The Brooklyn Union Natural Gas Conversion."

90. Massachusetts Department of Public Utilities, "Generic Investigation of the Facts Surrounding and the Ratemaking Treatment of the Costs of Investigating and Remediating Hazardous Wastes Associated with the Manufacture of Gas during the Period, 1822-1978."

91. See Dennis Unites (GEI Consultants, Inc.), "Environmental Impacts of Manufactured Gas Plant Demolition: Examples from Site Remediation Experience," available at http://www.geiconsultants.com/stuff/contentmgr/files/0/e3671c639fb4ba0de840765 c01ff3589/download/environmentalimpactsmgpdemo.pdf (accessed 4 August 2011). 
JANUARY

2014

VOL. 55

ously noted, consisted primarily of razing structures, filling pits, and conducting little or no environmental remediation.

During the 1970s, the nation became increasingly aware of the threat that wastes from past, as well as current, industries posed to environmental quality and human health. ${ }^{92}$ The most noted event was at Love Canal (1978), where Hooker Chemical had deposited barrels containing thousands of gallons of toxic wastes in an old canal bed, covering them over with layers of soil. These wastes had eventually leaked out, contaminating nearby residential areas and adjacent schools. Love Canal, however, was only the most prominent of these sites, and investigations soon showed that there were actually thousands of other sites where hazardous industrial wastes posed a threat to human health, often through soil contamination and groundwater pollution. ${ }^{93}$ In 1980, Congress enacted CERCLA (Comprehensive Environmental Response, Compensation, and Liability Act), popularly known as Superfund, designed to clean up sites contaminated with hazardous substances. The law created a tax on the chemical and petroleum industries and provided broad federal authority to respond directly to releases or threatened releases of hazardous substances that might endanger public health or the environment. CERCLA established prohibitions and requirements concerning closed and abandoned hazardous-waste sites; provided for the liability of persons responsible for the release of hazardous wastes at these sites; and established a trust fund to provide for cleanup when no responsible party could be identified. On 17 October 1986, Congress amended CERCLA, passing the Superfund Amendments and Reauthorization Act (SARA), which increased the funding for Superfund and provided, among other things, for innovative treatment technologies in cleanups and increased states' involvement in the Superfund program. ${ }^{94}$

The inventory of polluted industrial sites included large numbers of former manufactured gas plants, and by the 1980s, both the industry itself and the U.S. Environmental Protection Agency (EPA) had begun to grasp the magnitude of the problem. In 1985, the EPA issued a Survey of Town Gas and By-Product Production and Locations in the U.S. (1880-1950), including a list of municipal plants by state; it followed this up in 1987 with a more detailed study, U.S. Production of Manufactured Gases: Assessment of Past Disposal Practices. This later study reviewed the history of the "Town Gas Industry," types of production technologies, industry by-products and wastes, and the investigation and remediation of sites. ${ }^{95}$ At the same time,

92. In 1976, the U.S. Congress enacted the Resources and Recovery Act (RCRA) to establish a "cradle-to-grave" system governing hazardous waste from the point of generation to disposal.

93. Craig E. Colten and Peter N. Skinner, The Road to Love Canal, 89-90; Samuel P. Hays, Beauty, Health, and Permanence.

94. See EPA, "CERCLA Overview," available at http://www.epa.gov/superfund/policy/cercla.htm; and "SARA Overview," available at http://www.epa.gov/superfund/policy/sara.htm (both accessed 11 April 2011).

95. The Department of the Environment in Great Britain published a similar report 
the Gas Research Institute (GRI) - the research and development arm of the AGA-produced four volumes titled Management of Manufactured Gas Plant Sites that dealt with wastes and chemicals of concern, site investigation, risk assessment, and site restoration. These volumes, noted the GRI, presented "the full range of information necessary to investigate, perform a risk assessment, and select a restoration strategy for a worst-case site."96

As site examinations continued, the EPA refined and enlarged its understanding of the magnitude of the pollution problem, as is reflected in its 2010 Industrial Profile Fact Sheet for the manufactured gas industry:

Common waste products encountered at Superfund assessment and remediation projects include high concentrations of polynuclear aromatic hydrocarbons (PAHs), sulfur compounds, complex cyanide compounds and lower concentrations of volatile and phenolic compounds. These wastes are concentrated in a dense, aromatic coal tar and associated waste waters. This coal tar waste is typically found in large on-site pits, many of which are over 20 feet deep... . The most common metals [found] include aluminum, iron, lead, nickel, and chromium. The ash may be encountered on site mixed with the coal tar or as a separate waste pile. ... Groundwater may be contaminated as a result of leaching or percolation of surface and subsurface contaminants, surface impoundments and leaking process lines and tanks. ${ }^{97}$

These wastes were found at thousands of former MGP sites examined during the last several decades, although it was not until the early 1990s that the full extent of the environmental problems on these sites was appreciated.

\section{Conclusion}

Over time, a huge technical literature has developed on the environmental effects of the manufactured gas industry. Many case studies have been produced that clearly identify the extensive on-site pollution created by the industry, as well as off-site pollution. Critical questions are: Under what conditions did this pollution ensue? Did the nature of the gas-manufacturing process make extensive on- and off-site pollution inevitable? Was it the result of regular plant operations, or accidents, or did plant operatives and engineers deliberately "waste" by-products into the environment? Were engineers and managers in the manufactured gas industry aware,

in 1981 titled Problems Arising from the Redevelopment of Gas Works and Similar Sites, followed by a second edition in November 1987.

96. GRI, Management of Manufactured Gas Plant Sites. The report lists five types of major waste classifications based on a survey of thirty-three sites, all of which were adjacent to or within 500 feet of a body of water.

97. EPA, Mid-Atlantic Brownfields \& Land Revitalization, "Manufactured Gas Plants/Coal Tar Sites," available at http://www.epa.gov/reg3hwmd/bf-lr/regional/industry/manufactured.htm (accessed 12 November 2012). 
JANUARY

2014

VOL. 55 throughout its history, of the amount of damage their wastes could do to the environment, and did it matter to them? The record indicates that pollution was a product of everyday plant operations and of inevitable accidents and leaks, but it is also clear that, on occasion, plant personnel deliberately disposed of polluting by-products into the environment. ${ }^{98}$

In their valuable study The Road to Love Canal: Managing Industrial Waste before EPA, Craig Colten and Peter Skinner note that when forced to make choices about how to manage wastes (assuming that they understood the potential for the environmental damage that waste disposal presented), "decision makers considered or were guided by the public and corporate mores of the time, by statutory or common-law requirements, and by their own private value systems." The authors add that other pressures, such as competition, economic cycles, and levels of enforcement, affected these "sensitizers," with costs, legal constraints, and even ethical considerations being the primary factors. ${ }^{99}$

From the records, articles, and conference proceedings that were reviewed for this article, over the industry's history, it is possible to derive a picture of the thought processes of gas engineers regarding waste disposal. Undoubtedly, they preferred to sell by-products if a market was available. From this perspective, economic considerations ranked high in plant operations, and waste-disposal practices and solutions to by-product problems could be profitable. Advances in technology also helped reduce nuisances and made for more efficient plant operations. ${ }^{100}$

On the other hand, if no markets were available, operators would usually dispose of waste materials in the least costly method possible, even if this resulted in environmental damages. A revealing exchange occurred at the 1882 conference of the New England Gas Association, when a member admitted putting ammonia liquid from his MGP "into the harbor" if no market for it existed. Another association member called him a "Wicked man," insisting that there was no reason why MGPs should let their "ammoniacal [liquid] go to waste, or run into the rivers and make a nuisance to the works and to the neighbors" when it could be recycled and sold. ${ }^{101}$ While this was an argument from a conservation perspective, it also raised the issue of moral responsibility to "the neighbors." 102

98. See the analysis of Murphy, Sparacio, and Shields, "Manufactured Gas Plants." See also Allen W. Hatheway, "Lessons Learned from 20 Years' Remedial Work" and Remediation of Former Gas Plants and Other Coal-Tar Sites, 797-980.

99. Colten and Skinner, The Road to Love Canal, 6-10.

100. Timothy J. LeCain notes in his study of copper mining in Butte, Montana, that the mining company insisted that pollution-control measures be profitable, while mining engineers were confident that they could find a technological fix for pollution. See LeCain, Mass Destruction, 74-100.

101. Edwin T. Layton Jr. notes that engineers often had a "moral concern for the wellbeing of society" and were sensitive to public criticism of their use of technology, hence embracing conservationist ideas; see Layton, The Revolt of the Engineers, 62-64, 116.

102. At the 1877 meeting of the American Gas Light Association, J. R. Shotwell, an 
Historian Hugh Gorman, author of a definitive book on the history of the petroleum industry and the environment, notes that oil-refinery engineers generally did not see themselves "as polluters," since pollution streams from refineries had decreased over time due to their own efforts; they frequently disregarded pollution complaints as insignificant. ${ }^{103}$ Engineers at gas plants reacted in the same way. In 1920, for instance, at the AGA meeting where Willien presented his report detailing types of MGP pollution, F. C. Freeman, a Rhode Island gas engineer, protested to Willien that "gas engineers have given considerable thought to gas plant wastes, and most gas works operators are keenly attentive to the condition and treatment of their wastes to avoid stream and harbor pollution." 104 The record suggests otherwise. In 1907, in a comment at the Boston Society of Civil Engineers after he delivered his paper on "Wastes from Lowell Gas Light Company's Yards," Safford attributed the lack of records on waste problems to the belief of MGP operators that "anything can be put into sewers, and the unwillingness on the part of gas companies to acknowledge that the bad conditions are produced by the wastes from their works." 105

Nuisance suits existed as a possible restraint on waste-disposal practices. Shelton's 1899 paper “The Nuisance Question in Gas Works" is a good indication of the awareness of engineers of the threat, as were frequent notices of nuisance suits in the gas-industry literature. However, while the risk of suits undoubtedly shaped the industry's waste-disposal practices to an extent, it probably had a limited effect because of the reluctance of courts to grant sizeable awards or to issue injunctions forcing a plant to cease operations. This is not to say that no damages were ever awarded or injunctions issued-they were, but it is unlikely that they served as a serious constraint. ${ }^{106}$

It is informative to compare the position of the AGA with that of the API in regard to goals and operations. The two industries faced the threat of federal regulation after World War I because of oil- and gas-waste pol-

employee of the Rahway Gas-Light Company, delivered a paper. See Shotwell, "Method of Purifying the Residuum of Gas Works before Allowing It to Pass Off into the Water," 134. Spencer Baird, U.S. Commissioner of Fish and Fisheries, who was concerned with the effects of gas-house wastes on fish, attended the meeting and requested a description of the process. Shotwell obliged, and in his letter to Baird noted that the company had tried to "avoid the annoyance to the community."

103. Hugh Gorman, Refining Efficiency, 105. Benjamin Ross and Steven Amter examine the negative effects of the chemical industry on the environment in The Polluters.

104. Noted in the discussion after Willien's report, "Report of the Committee on Disposal of Waste from Gas Plants," 440-63. Hatheway notes that contamination found at former MGP sites is "the result of particular handling and management practices employed by the gas men," and that the "gas men who manufactured that product and, who, in that endeavor, generated both residuals and wastes were well informed of the dangerous properties and characteristics of these elements and compounds" (Remediation of Former Gas Plants and Other Coal-Tar Sites, 312, 378, 381).

105. Safford, "Wastes from Lowell Gas Light Company's Yards," 183-84.

106. Gas Age published a regular column titled "Legal Decisions Affecting Gas Companies." 
JANUARY

2014

VOL. 55

lution of U.S. waterways. Both hoped to avoid governmental intervention in their operations, to better their public images, and to improve coordination by collecting and disseminating statistical information, publishing proceedings and magazines, presenting the industry in a positive manner, and promoting industry-wide publicity attempts to explain their positions to both the government and public. ${ }^{107}$ For instance, the AGA published AGA Monthly, which featured shorter papers on the subjects covered in the AGA annual proceedings in addition to professional news, while the API published a monthly Bulletin that provided similar information. AGA Monthly also reported on proceeding at the API annual meetings. ${ }^{108}$

Each industry association formed a committee concerned with pollution. The AGA was the first, in 1918 creating its waste-disposal committee, while in 1924, the API issued its first official set of industrial standards. Gorman views these as an indirect move toward showing that engineers could use efficiency to reduce wastes and control pollution. ${ }^{109}$ In the later 1920s, after the Corps of Engineers reported that oil pollution still remained a problem, a new industrial-waste pollution-control bill was introduced in the House of Representatives. This persuaded the API to task its technical committees to collect information about the industry's waste-disposal practices-similar to the AGA's action almost a decade before. The operations of the API committee, however, were more systematic and thorough than those of the AGA. ${ }^{110}$ The API's pollution-control committee also produced a manual in 1930 to set standards for the discharge of refinery wastes, and to prove to the U.S. Congress that the industry could regulate itself. ${ }^{11}$ The AGA did not produce such a manual. In 1934, the PCGA produced a detailed handbook on the manufactured gas industry, which was "endorsed by the directors of the American Gas Association." The single reference it contained to waste disposal concerned the effect of phenols on public water supplies. ${ }^{112}$

This review of the waste-disposal practices of the manufactured gas

107. The AGA's Statement of Purpose stated that it had been founded to promote the gas industry, to serve the public, to increase the effectiveness of gas service, to extend efficient management, to promote closer relations and cooperation among the industry's branches, to advance the science of gas-making, and to cooperate with other organizations working toward "economic advancement, accident prevention, conservation, standardization and other activities" (AGA: What It Is-What It Does). See also George B. Cortelyou, "The Mission of the American Gas Association." For the mission of the API, see Pratt, "Creating Coordination in the Modern Petroleum Industry."

108. See "Thoughts for the Gas Manufacturer from the Second Annual Meeting of the American Petroleum Institute.”

109. Gorman, Refining Efficiency, 143.

110. Ibid., 153.

111. Refineries did reduce their discharges of pollution-causing wastes during the 1930 s and '40s through the use of the manual and the larger scale of refinery operations. See ibid., 215-24; and Colten and Skinner, The Road to Love Canal, 89-90.

112. Gas Engineers' Handbook Committee of the PCGA, Gas Engineers' Handbook, 443. 
industry demonstrates that the industry had a long-term record of polluting the environment. Was it possible to operate an MGP without some damage to the air, land, and water environments? The character of the industry and of the various processes used to produce gas made some pollution inevitable, but the literature suggests that substantial amounts could have been prevented. The legacy price paid by society for the operations of this industry was thousands of sites badly contaminated with a variety of toxic MGP wastes (figs. 6, 7).

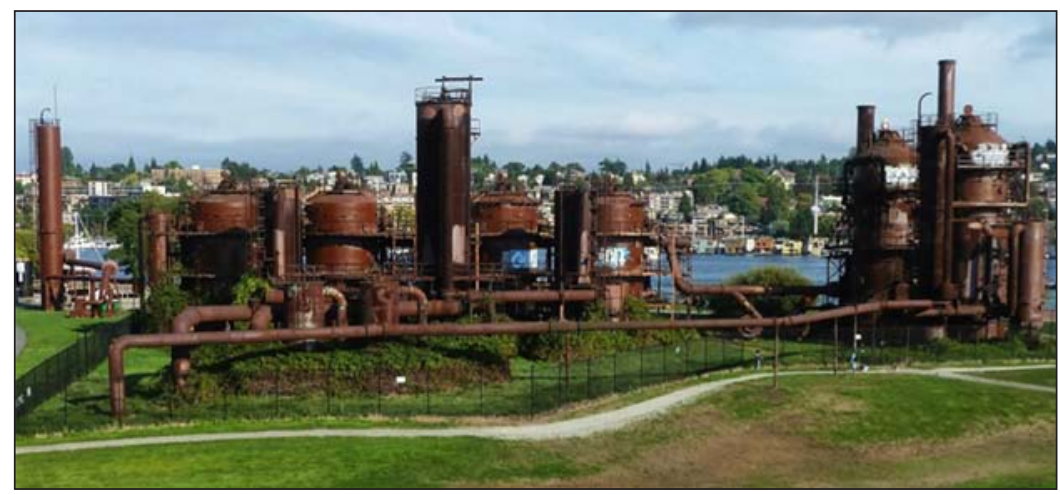

FIG. 6 The Oil Gas Seattle manufactured gas plant in 2013 after decommissioning. It is now Gas Works Park. (Source: Photograph by Joanna Tarr, reprinted with permission.)

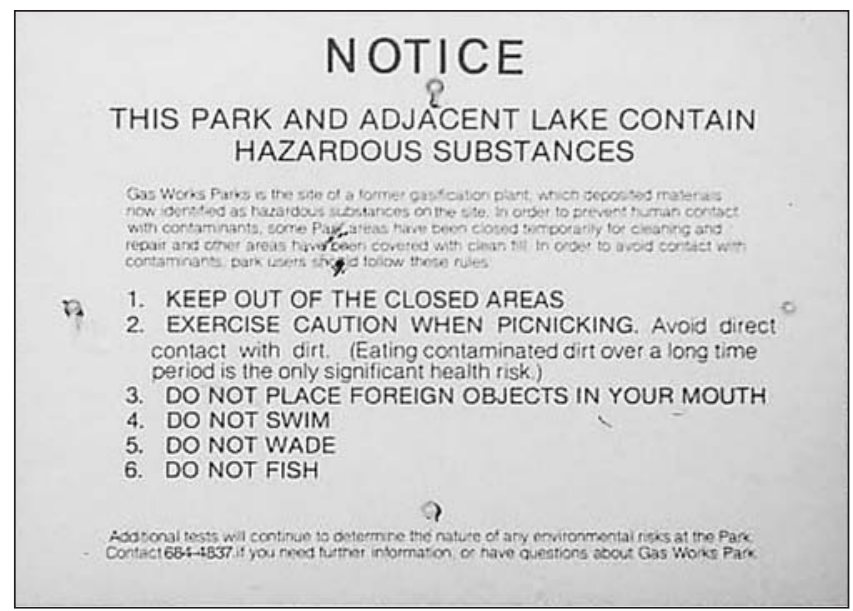

FIG. 7 Warning sign, Seattle Gas Works Park, ca.1996. (Source: Photograph by the author.) 


\section{Bibliography}

\section{Archival Sources}

Archives of the Massachusetts State Board of Health, State Archives, Boston

Archives of the Minnesota Department of Health and the Minnesota

JANUARY

2014

VOL. 55

Commissioner of Game and Fish, State Archives, Minneapolis

Archives of the Pennsylvania Sanitary Water Board, State Archives, Harrisburg

Archives of the U.S. Army Corps of Engineers, National Archives, Washington, D.C.

Archives of the U.S. Fish and Wildlife Service, National Archives, Washington, D.C.

\section{Published Sources}

Abell, H. C. "Changing Over a City's Gas Supply." Natural Gas 10 (June 1929): 36, 38, 46, 54, 56, 62, 65-66, 68, 70-71.

American Gas Association (AGA). AGA: What It Is-What It Does. New York: AGA, 1920.

. "Report of 1920 Waste Disposal Committee." In Second Annual Convention: Technical Section, 413-64. New York: AGA, 1920.

Anderson, Arthur R. "Natural Gas Comes to Detroit: Appliance Conversion." Gas Age Record and Natural Gas, 26 December 1936, 703-4.

Brown, R. B. "Disposal of Wastes from Gas Plants." AGA Monthly 1 (April 1919): 189-93.

Carswell, E. D. "Tar Emulsion." Proceedings, Twentieth Annual Convention Southern Gas Association, 17-19 April 1928, 56.

Castaneda, Christopher J. Regulated Enterprise: Natural Gas Pipelines and Northeastern Markets, 1938-1954. Columbus: Ohio State University Press, 1995.

. Invisible Fuel: Manufactured and Natural Gas in America, 18002000. New York: Twayne, 1999.

, and Joseph A. Pratt. Texas to the East: A Strategic History of Texas Eastern Corporation. College Station: Texas A\&M Press, 1993.

Chandler, Charles F. Report on the Gas Nuisance in New York. New York: D. Appleton, 1870.

Colten, Craig E. "A Historical Perspective on Industrial Wastes and Groundwater Contamination." Geographical Review 81 (April 1991): 215-28.

. "Illinois River Pollution Control." In The American Environment: Interpretation of Past Geographies, edited by Larry M. Dilsaver and Craig E. Colten, 196-205. Lanham, MD: Rowman \& Littlefield Publishers, 1992.

, and Peter N. Skinner. The Road to Love Canal: Managing Industrial Waste before EPA. Austin: University of Texas Press, 1996.

"Con Edison Turns on the Gas." BusinessWeek, 23 June 1951, 108-13. 
Cortelyou, George B. “The Mission of the American Gas Association." AGA Monthly 2, no. 12 (1920): 723.

Desrochers, Pierre. "Victorian Pioneers of Corporate Sustainability." Business History Review 83 (2009): 703-29.

Deuber, Carl G. "Effects on Trees of an Illuminating Gas in the Soil." Plant Physiology 11 (April 1936): 401-412.

“The Disposal of the Waste Products of Gas Works." Engineering Record 58 (17 October 1908): 434-43.

Dutton, L. R. "The Disposal of Waste Water from Water Gas Plants on Streams Adjacent to Parks.” AGA Monthly 1 (April 1919): 189-93.

Ellis, M. M. "Detection and Measurement of Stream Pollution." Bulletin of the U.S. Bureau of Fisheries 48 (1937): 365-437.

EPA, Mid-Atlantic Brownfields \& Land Revitalization. "Manufactured Gas Plants/Coal Tar Sites," available at http://www.epa.gov/reg3hwmd/bflr/regional/industry/manufactured.htm (accessed 12 November 2012).

Esser, Stephen C. "Long-term Changes in Some Finfishes of the HudsonRaritan Estuary." In Ecological Stress and the New York Bight: Science and Management, edited by G. F. Mayer, 299-314. Columbia, SC: Estuarine Research Federation, 1981.

Fieldner, A. C. "Recent Developments in By-Products from Bituminous Coal.” R.I. 3079. U.S. Bureau of Mines, 1931.

Franz, David R. "An Historical Perspective on Mollusks in Lower New York Harbor, with Emphasis on Oysters." In Ecological Stress and the New York Bight: Science and Management, edited by G. F. Mayer, 18197. Columbia, SC: Estuarine Research Federation, 1981.

Gas Engineers' Handbook Committee of the PCGA. Gas Engineers' Handbook. New York: McGraw-Hill, 1934.

Gas Research Institute (GRI). Management of Manufactured Gas Plant Sites, 4 vols. Pittsburgh: Remediation Technologies, 1987.

Goodell, E. B. A Review of the Laws Forbidding Pollution of Inland Waters in the U.S. U.S.G.S. Water Supply Papers, 2nd ed. U.S.G.S. Paper no. 152. Washington, DC: GPO, 1905.

Gorman, Hugh. Refining Efficiency: Pollution Concerns, Regulatory Mechanisms, and Technological Change in the U.S. Petroleum Industry. Akron, OH: University of Akron Press, 2001.

Gould, Jacob Martin. Output and Productivity in the Electric and Gas Utilities. Cambridge, MA: National Bureau of Economic Research, 1946.

Great Britain, Department of the Environment. Problems Arising from the Redevelopment of Gas Works and Similar Sites, 2nd ed. London: HMSO, 1987.

Grozier, David. “The Brooklyn Union Natural Gas Conversion: Biggest Changeover in the World." Gas Age 111 (1 Januray 1953): 39-41.

Gutsell, J. S. Danger to Fisheries from Oil and Tar Pollution of Waters. Bureau of Fisheries Document no. 910. Washington, DC: GPO, 1921. 
Hansen, Paul. "Disposal of Gas House Wastes.” American Gas Light Journal, 10 April 1916, 228-29.

"Disposal of Gas House Wastes." Proceedings of the Illinois Gas Association 12 (1916): 125-35.

Harkins, Scott M., Robert S. Truesdale, Ronald Hill, Paula Hoffman, and

JANUARY

2014

VOL. 55 Steven Winters. U.S. Production of Manufactured Gases: Assessment of Past Disposal Practices. Cincinnati: EPA, 1988.

Hart, W. B. "Stream Protection and Management." Proceedings of the AGA 32 (1950): 412-13.

Hatheway, Allen W. "Manufactured Gas in California, 1852-1940: Basis for Remedial Action." Practice Periodical of Hazardous, Toxic, and Radioactive Waste Management 3 (July 1999): 32-146.

. "Lessons Learned from 20 Years' Remedial Work amongst Derelict Gasworks, Gasworks Dumps, Coke Ovens \& Other Coal-Tar Sites.” In Geologically Active: Proceedings of the 11th IAEG Congress. Auckland, New Zealand, 5-10 September 2010, edited by A. L. Williams et al., 4191-98. Boca Raton, FL: CRC Press, 2010.

Remediation of Former Gas Plants and Other Coal-Tar Sites. Boca Raton, FL: CRC Press, 2012.

Hays, Samuel P. Conservation and the Gospel of Efficiency: The Progressive Conservation Movement, 1890-1920. Cambridge, MA: Harvard University Press, 1959.

Beauty, Health, and Permanence: Environmental Politics in the United States, 1955-1985. New York: Cambridge University Press, 1987.

Herbert, John H. Clean Cheap Heat: The Development of Residential Markets for Natural Gas in the United States. New York: Praeger, 1992.

Hulling, Scott G., and James W. Weaver. "Dense Nonaqueous Phase Liquids.” EPA Ground Water Issue, EPA/540/4-91-002, March 1991.

Hurley, Andrew. "Creating Ecological Wastelands: Oil Pollution in New York City, 1870-1900.” Journal of Urban History 20 (May 1994): 34064.

Illinois, State of, Rivers and Lakes Commission. Annual Reports of the Rivers and Lakes Commission of Illinois. Springfield: State of Illinois, 1913-14, 1915, 1916, 1924-25, 1925-26, 1927-28, 1930-31.

. Pollution of Streams in Illinois. Bulletin no. 24. Springfield: State of Illinois, 1927.

Keiner, Christine. The Oyster Question: Scientists, Watermen, and the Maryland Chesapeake Bay since 1880. Athens: University of Georgia Press, 2009.

Kurlansky, Mark. The Big Oyster: History on the Half Shell. New York: Ballantine Books, 2006.

Layton, Edwin T., Jr. The Revolt of the Engineers: Social Responsibility and the American Engineering Profession. Cleveland: Case Western Reserve University Press, 1971. 
LeCain, Timothy J. Mass Destruction: The Men and Giant Mines That Wired America and Scarred the Planet. New Brunswick, NJ: Rutgers University Press, 2009.

Leitch, R. D. "Stream Pollution by Wastes from By-Product Coke Ovens: A Review, with Special Reference to Methods of Disposal.” Public Health Reports 40 (25 September 1925): 2021-26.

Lincoln, Edward W. Trial: Commonwealth vs. The Worcester Gas Light Company-Indictment for Nuisance. Worcester, MA: Worcester Gas Light Company, 1855.

Marsh, M. C. The Effects of Some Industrial Wastes on Fishes. U.S. Geological Survey, Water Supply and Irrigation Paper no. 192. Washington, DC: GPO, 1907.

Massachusetts Commissioners on Fisheries and Game. Report to the Senate Concerning Obstructions to the Passage of Fish in the Connecticut and Merrimack Rivers. Boston, 1866.

Massachusetts Department of Public Utilities. "Generic Investigation of the Facts Surrounding and the Ratemaking Treatment of the Costs of Investigating and Remediating Hazardous Wastes Associated with the Manufacture of Gas during the Period, 1822-1978" (n.p.; author's collection), 25 May 1990.

Matthews, Derek. "The Technical Transformation of the Late-NineteenthCentury Gas Industry." Journal of Economic History 47 (December 1987): 967-80.

McBride, R. S. "Manufactured Gas and Byproducts in 1920." In Mineral Resources of the United States, edited by U.S. Bureau of Mines/USGS, 439-97. Washington, DC: GPO, 1920.

McCay, Bonnie J. "Oysters, Public Trust, and the Law in New Jersey." In New Jersey's Environments: Past, Present, and Future, edited by Neil M. Maher, 53-64. New Brunswick, NJ: Rutgers University Press, 2006.

McKay, Wm. E. “Tar and Water from Water-Gas." Proceedings of the American Gas Light Association 46 (16-18 October 1901): xxvii.

Mellhenny, James S. "Removal of the Last Traces of Oil and Tar from Water of Condensation.” American Gas Light Journal, 15 May 1905, 766-68.

Mershon, Sherie R., and Joel A. Tarr. "Strategies for Clean Air: The Pittsburgh and Allegheny County Smoke Control Movements, 1940-1960." In Devastation and Renewal: An Environmental History of Pittsburgh and Its Region, edited by Joel A. Tarr, 145-73. Pittsburgh: University of Pittsburgh Press, 2005.

Mitchell, Philip H. “The Effect of Water-Gas Tar on Oysters.” Bulletin of the U.S. Bureau of Fisheries 32 (1912): 201-66.

Montgomery, Stanley, and Earle B. Phelps. Stream Pollution: A Digest of Judicial Decisions and a Compilation of Legislation Relating to the Subject. Public Health Bulletin no. 87. Washington, DC: GPO, 1918. 
Morgan, Jerome J., and Charles F. Stolzenbach. "Heavy Oil Tar Emulsions in the Water Gas Process, Pt. I." AGA Monthly 32 (July 1934): 245-48.

. "Heavy Oil Tar Emulsions in the Water Gas Process, Pt. II." AGA Monthly 33 (August 1934): 277-80.

Munroe, Charles E. "By-Products in Gas Manufacture." Journal of the Franklin Institute 174, no. 1 (1912): 1-34.

JANUARY

2014

VOL. 55

Murphy, Brian L., Tarn Sparacio, and Walter J. Shields. "Manufactured Gas Plants-Processes, Historical Development, and Key Issues in Insurance Coverage Disputes." Environmental Forensics 6 (2005): 161-73.

Nelson, Thurlow C. The Conservation of New Jersey's Oyster Industry. New Jersey Board of Shell Fisheries Report. Trenton: New Jersey Board of Shell Fisheries, 1920.

New York State Assembly. "Report of J. W. Mersereau, State Oyster Protector." New York State Assembly Document no. 37, Eighteenth Report of the New York Commissioner of Fisheries, 1890.

New York State Conservation Commission. Thirteenth Annual Report for the Year 1923. Albany, NY: J. B. Lyon Company, 1924.

New York State Legislature. "Laws . . Passed at Sixty-Eighth Session." Journal of the Senate of the State of New York (13 March 1845), chap. 201: 229, 300, 523, 726.

"Laws ... Passed at the One Hundred and Fifth Session" (1882), chap. 410, 208.

Novak, William J. The People's Welfare: Law and Regulation in NineteenthCentury America. Chapel Hill: University of North Carolina Press, 1996.

Parks, F. B. "Carbureted Water Gas from Heavy Oils with Related Tar and Emulsion Problems." Proceedings of the AGA 17 (1935): 759-67.

"Pollution of Streams." Progressive Age 24 (1 December 1906): 739-40.

"The Pollution of Streams." In Annual Report of the Massachusetts State Board of Health, 1877. Boston, 1877, 43.

Powell, A. R. "Report of the Subcommittee on Disposal of Waste from Gas Plants." Proceedings of the AGA 11 (1929): 928-32.

Powers, Edwin B. The Goldfish as a Test Animal in the Study of Toxicity. Study no. 109. Champaign: Zoological Laboratory of the University of Illinois, 1918.

Pratt, Joseph A. "Creating Coordination in the Modern Petroleum Industry: The American Petroleum Institute and the Emergence of Secondary Organizations in Oil." In Research in Economic History, vol. 8, edited by Paul Uselding, 180-215. Greenwich, CT: JAI Press, 1984.

Black Waters: Responses to America's First Oil Pollution Crisis, Essays in Public Works History, vol. 27. Kansas City: APWA Press, 2008.

"Progress Report of the Committee on Industrial Wastes in Relation to Water Supply." Journal of the American Water Works Association 10 (1923): 420-22. 
"Progress Report on Recent Developments in the Field of Industrial Wastes in Relation to Water Supply." Journal of the American Water Works Association 16 (1926): 302-29.

"Protecting Sheepshead Bay." Brooklyn Eagle, 13 July 1881.

Rose, Mark H. Cities of Light and Heat. State College: Pennsylvania State University Press, 1995.

Rosen, Christine Meisner. “'Knowing' Industrial Pollution: Nuisance Law and the Power of Tradition in a Time of Rapid Economic Change, 1840-1864." Environmental History 8 (October 2003): 565-97.

. "Regulating the New Industrial Air Pollution: The Struggle Begins." In Mindsets and Movements: A History of America's Early Struggles with Industrial Pollution, 1840-1900. Cambridge, MA: Harvard University Press (forthcoming).

Ross, Benjamin, and Steven Amter. The Polluters: The Making of Our Chemically Altered Environment. New York: Oxford University Press, 2010.

Safford, Arthur T. "Wastes from Lowell Gas Light Company's Yards." Journal of the Association of Engineering Societies 39 (1907): 169-98.

"Sanitary Ordinances." Brooklyn Eagle, 8 September 1875.

Schivelbusch, Wolfgang. Disenchanted Night: The Industrialization of Light in the Nineteenth Century. Berkeley: University of California Press, 1995.

Schlichtmann, Jan Richard. The Known and Present Danger: The Colonial Gas Company and Coal Gas Waste in Lowell, Massachusetts. Boston: Bateman \& Slate, Inc., 1988.

Schniewind, F. "The Everett Coke-Oven Gas Plant." Progressive Age 17 (15 August 1899): 366-90.

Sedgwick, W. T., and F. Schneider Jr. "On the Relation of Illuminating Gas to Public Health." Journal of Infectious Diseases 9 (November 1911): 380-409.

Seeley, H. K. "Report of the Subcommittee on Water Gas Tar Emulsions, Their Prevention, Treatment, and Utilization." Proceedings of the AGA 9 (1927): 1078-84.

. "Report of the Subcommittee on Water Gas Tar Production." Proceedings of the AGA 10 (1928): 1344.

Shelford, Victor E. "An Experimental Study of the Effects of Gas Waste upon Fishes, with Special Reference to Stream Pollution." Bulletin of the Illinois State Laboratory of Natural History 5, no. 11 (1917): 381-412.

Shelton, Frederick H. "The Nuisance Question in Gas Works." Progressive Age 17 (15 March 1899): 109-10.

. "The Nuisance Question in Gas Works." Proceedings of the 29th Annual Meeting of the Association of New England Gas Engineers (1900): 314-32.

Shotwell, J. H. "Method of Purifying the Residuum of Gas Works before Allowing It to Pass Off into the Water." American Gas Light Journal 5 (2 October 1877): 134. 
"State Protection for Public Waters." Brooklyn Eagle, 12 May 1886.

Steere, F. W. "Producer Gas Technology." In American Fuels, vol. 2, edited by Raymond Foss Bacon and William Allen Hamor, 914-94. New York: McGraw-Hill, 1922.

Stotz, Louis, and Alexander Jamison. History of the Gas Industry. New York: Stettiner Brothers, 1938.

JANUARY

2014

VOL. 55

Tarr, Joel A. "Searching for a Sink for an Industrial Waste." In The Search for the Ultimate Sink: Urban Pollution in Historical Perspectives, 385412. Akron, OH: University of Akron Press, 1996.

. "Transforming an Energy System: The Evolution of the Manufactured Gas Industry and the Transition to Natural Gas in the United States (1807-1954)." In The Governance of Large Technical Systems, edited by Olivier Coutard, 19-37. New York: Rutledge, 1999.

. "The City and Technology." In A Companion to American Technology, edited by Carroll Pursell, 97-112. Oxford: Blackwell Publishing, 2005.

Thorsheim, Peter. Inventing Pollution: Coal, Smoke, and Culture in Britain since 1800. Athens: Ohio University Press, 2006.

"Thoughts for the Gas Manufacturer from the Second Annual Meeting of the American Petroleum Institute." AGA Monthly 4 (February 1922): 101.

Tomory, Leslie. “Building the First Gas Network, 1812-1920.” Technology and Culture 52, no. 1 (2011): 75-102.

. "The Environmental History of the Early British Gas Industry, 1812-1830.” Environmental History 17, no. 1 (2012): 29-54.

. Progressive Enlightenment: The Origins of the Gaslight Industry, 1780-1820. Cambridge, MA: MIT Press, 2012.

Troesken, Werner. Why Regulate Utilities? The New Institutional Economics and the Chicago Gas Industry, 1849-1924. Ann Arbor: University of Michigan Press, 1996.

"Regime Change and Corruption: A History of Public Utility Regulation." In Corruption and Reform: Lessons from America's Economic History, edited by Edward L. Glaeser and Claudia Goldin, 259-83. Chicago: University of Chicago Press, 2006.

Tussing, Arlon R., and Connie C. Barlow. The Natural Gas Industry: Evolution, Structure, and Economics. Pensacola, FL: Ballinger Publishing, 1984.

U.S. Bureau of Mines. Mineral Resources. Washington, DC: GPO, 1927, 1932-54.

U.S. Congress. House, Committee on Rivers and Harbors. Pollution of Navigable Waters. Hearings on the Subject of the Pollution of Navigable Waters Held before the Committee on Rivers and Harbors, House of Representatives. 67th Cong., 1st sess., 25 October 1921. Washington, DC: GPO, 1921, 5-86. 
. Senate, Committee on Commerce. "Statement of Capt. J. C. Fremont, United States Navy, Supervisor New York Harbor." In Pollution of Navigable Waters: Hearing before a Subcommittee of the Committee on Commerce, United States Senate. 68th Cong., 1st sess., 9 January 1924, on S.42, S.936, and S.1388. Washington, DC: GPO, 1924, 37-40.

Utica Gas and Electric Company. The Upper Mohawk Valley: Land of Industry. Utica, NY: UGEC, 1923.

Ward, Henry B. Stream Pollution in New York State: A Preliminary Investigation of the Problem from the Standpoint of the Biologist. Albany: New York State Conservation Commission, 1919.

Wardale, N. H. "Gas Plant Waste Disposal." Proceedings of the PCGA 37 (1930): 363-82.

Warrick, L. F. "Stream Protection and Management." Proceedings of the AGA 32 (1950): 413-17.

Wehrle, George. "Effect of Change-Over to Natural Gas." Oil and Gas Journal 29 (1931): 155-56.

Whipple, George C. "Gas Wastes." In Report of the State Sewerage Commission to the [New Jersey] Legislature of 1908, 145-69. Somerville, NJ: State Printer, 1908.

"Willien, Associate Director Institute of Gas Technology." American Gas Journal (August 1944): 44.

Willien, Leon J. "Report of the Committee on Disposal of Waste from Gas Plants." Proceedings of the AGA 1 (1919): 274-80.

. "Disposal of Waste from Gas Plants." American Gas Engineering Journal 111 (6 November 1920): 363.

. "To Avoid Stream Pollution." The Gas Record 18 (1920): 31-34.

. "Report of the Committee on Waste Disposal from Gas Plants." AGA Monthly 4 (1923): 501. . "Water Gas Tar Emulsions." Proceedings of the AGA 5 (1923): 1349. 